\title{
Better Alone Than in Bad Company: New Species of Caudofoveate Limifossorid (Mollusca, Aplacophora) Unravels Patterns of Distribution Hidden in the Deep Atlantic
}

\author{
Flávio Dias Passos ${ }^{1 *}$, Paulo Vinicius Ferraz Corrêa ${ }^{2}$ and Marcel Sabino Miranda ${ }^{1}$ \\ 'Laboratory of Malacology, Department of Animal Biology, Institute of Biology, University of Campinas, Campinas, Brazil, \\ ${ }^{2}$ Laboratory of Ecology and Evolution of Deep Sea, Department of Biological Oceanography, Oceanographic Institute, \\ University of São Paulo, São Paulo, Brazil
}

\section{OPEN ACCESS}

Edited by:

Kevin Kocot,

University of Alabama, United States

Reviewed by:

Ekin Tilic,

University of Copenhagen, Denmark

Emanuel Redl,

University of Vienna, Austria

Nina Therese Mikkelsen,

University of Bergen, Norway

${ }^{*}$ Correspondence:

Flávio Dias Passos

flaviodp@unicamp.br

Specialty section:

This article was submitted to

Deep-Sea Environments and Ecology,

a section of the journal

Frontiers in Marine Science

Received: 18 February 2021

Accepted: 20 July 2021

Published: 11 August 2021

Citation:

Passos FD, Corrêa PVF and Miranda MS (2021) Better Alone Than in Bad Company: New Species

of Caudofoveate Limifossorid

(Mollusca, Aplacophora) Unravels Patterns of Distribution Hidden in the Deep Atlantic.

Front. Mar. Sci. 8:669478. doi: 10.3389/fmars.2021.669478
Aplacophorans are common inhabitants of the deep-sea, where many places remain unexplored regarding their biodiversity. Filling a gap in knowledge about these animals from the South Atlantic, Scutopus variabilis sp. nov. (Caudofoveata, Limifossoridae) is described; further, species distribution modelling (SDM) was performed to elucidate the distribution patterns of Atlantic species of Scutopus. The type materials of S. megaradulatus Salvini-Plawen (1972) and S. chilensis Salvini-Plawen (1972), were examined and a search was performed for specimens of Scutopus held in museum collections. Scutopus variabilis sp. nov. has a slender and highly variable body form and a very distinct suture line is present midventrally. Two dominant types of trunk sclerites were observed by Scanning Electron Microscopy (SEM): one elongated with lateral margins slightly concave in medial portion, and another longer, with narrower base; its radula bears up to eight rows of heavily sclerotized teeth bearing 12-16 small denticles. The species occurs in a wide bathymetric range $(40-1300 \mathrm{~m})$, being more abundant at the edge between the continental shelf and upper slope. Outside the areas from where these samples were obtained, suitable areas for $S$. variabilis $\mathrm{sp}$. nov. were found in the Southern Caribbean Sea (from where S. megaradulatus is recorded) and in the Brazilian Northern coast; the Gulf of Mexico and the Brazilian Northeastern coasts were found as unsuitable. Species of Scutopus appear to exhibit different patterns of geographical distribution: the European S. ventrolineatus Salvini-Plawen (1968) and S. robustus Salvini-Plawen (1970) are known as widely distributed, while non-European representants, the American S. megaradulatus, S. chilensis and S. variabilis sp. nov., and the Japanese S. schanderi Saito and Salvini-Plawen (2014) and S. hamatamil Saito and Salvini-Plawen (2014) have more restricted distributions. However, clear and definite patterns of distribution of some of these species are probably blurred by sampling bias, for the European area is better studied. In the Atlantic, the SDM showed that species of Scutopus occur in a way that overlapping is minimized. Great sampling efforts combined with detailed descriptions based on SEM have revealed an interesting, abundant and up to now undescribed Brazilian deep-sea malacofauna.

Keywords: taxonomy, biogeography, species distribution modeling, Caudofoveata, Limifossoridae 


\section{INTRODUCTION}

Ubiquitous among the deep-sea organisms, aplacophorans form a molluscan group of particular phylogenetic interest (e.g., Kocot et al., 2011; Smith et al., 2011; Vinther et al., 2012, 2017; Mikkelsen et al., 2018, 2019), ecological importance (Scheltema, 1987, 1997; Scheltema and Ivanov, 2009), and biogeographical relevance (Scheltema, 1985; Ivanov and Scheltema, 2008; Corrêa et al., 2014, 2018; Bergmeier et al., 2017, 2019; Cobo and Kocot, 2020). They are generally characterized by their wormlike bodies covered by sclerites, and formed by two clades: Solenogastres, which are epifaunal and bear a ventral pedal furrow, and Caudofoveata, whose species are infaunal, without a ventral locomotory organ, and have an oral shield (that is absent in solenogasters). A total of 420 species of aplacophorans have been described so far, most of them occurring on the continental slope (Todt, 2013).

In the deep Atlantic Ocean, most reports on caudofoveates are for species from both European or North American waters, and fewer are based on specimens collected in the Southern Hemisphere. For the Brazilian coast (Southwestern Atlantic), in particular, eight species are known: Chevroderma turnerae Scheltema, 1985 recorded by Scheltema (1985) and Ivanov and Scheltema (2008), and Spathoderma bulbosum Ivanov and Scheltema, 2008 by Ivanov and Scheltema (2008); Falcidens targatus Salvini-Plawen, 1992 and F. acutargatus Salvini-Plawen, 1992 studied by Corrêa et al. (2014); Claviderma amplum Ivanov and Scheltema, 2008, C. crassum Ivanov and Scheltema, 2008 and C. virium Corrêa, Miranda and Passos, 2018 investigated by Corrêa et al. (2018); and F. australocaudatus Passos, Corrêa and Todt, 2016 described by Passos et al. (2018). Passos et al. (2019) have summarized all the records of aplacophorans from Brazilian waters up to that time, pointing out that most of them are from restricted oil-rich areas, there remaining large parts of its coast in which these molluscs were never reported (as its southernmost and northernmost portions), and that there are many other species to be investigated.

In the present contribution, a new species of the genus Scutopus Salvini-Plawen, 1968 is described, through the analysis of many specimens collected along the southeastern and southern coasts of Brazil, with some records for regions never explored before. This genus of Caudofoveata was created by SalviniPlawen (1968), based on the description of S. ventrolineatus Salvini-Plawen, 1968, originally discovered near Bergen, Norway, Scandinavia. Afterward, a second European species was described by Salvini-Plawen (1970), S. robustus Salvini-Plawen, 1970, and two others by Salvini-Plawen (1972), S. megaradulatus SalviniPlawen, 1972 and S. chilensis Salvini-Plawen, 1972, from the Caribbean Sea and Chile, respectively. More recently, Saito and Salvini-Plawen (2014) recorded S. schanderi Saito and SalviniPlawen, 2014 and S. hamatanii Saito and Salvini-Plawen, 2014 from the Sea of Japan. The Brazilian new species is here described based on the general body morphology and on the details of its oral shield, sclerites, and radula, in comparison with those congeneric six species; further, their bathymetric and geographical distributions are modeled and discussed regarding how these can advance delineation and identification of deep-sea caudofoveate species. It is here emphasized that this new species has a highly variable body form, and only through the observation of the many available specimens it was possible to describe it in detail, complementing ongoing recent discoveries that have been performed on the malacofauna of the Brazilian deep-sea waters.

\section{MATERIALS AND METHODS}

Most specimens were collected off the coasts of the Espírito Santo (ES) and Rio de Janeiro (RJ) States, southeast Brazil, obtained from bottom sediment samples collected by box-corers and Van Veen grabs, through the activities of the Projects "Habitats" and "Ambes" [for details about these projects, see Passos and Machado (2014) and Machado and Passos (2016)]. These samples were initially fixed in $4 \%$ formaldehyde and after sieving the animals were sorted and transferred to a solution of $70 \%$ ethanol. Apart from the material of these projects, other samples were collected off the States of São Paulo (SP) (also in the southeast), and in the southern States of Paraná (PR) and Rio Grande do Sul (RS). These latter samples were obtained by three research projects: "Projeto Integrado," which occurred from 1985 to 1986 and collected in the shelf of Ubatuba (São Paulo) (Pires-Vanin and Matsuura, 1993), and by the Projects "MBT" and "Revizee," in which more scattered bottom samplings were performed along all this area, the former in 1970/1, the latter in 1998/9. These materials are deposited in the molluscan collections of the following institutions: Museum of Zoology of the State University of Campinas (ZUEC APL), Campinas (SP), Museum of Zoology of University of São Paulo (MZSP), SP, National Museum of Rio de Janeiro (MNRJ), RJ, and Museum of Zoology of Federal University of Sergipe (CZUFS APL), São Cristóvão (SE), all in Brazil.

The animals were initially observed under stereomicroscopes, and then some were sorted for more detailed analysis using Scanning Electron Microscopy (SEM). The methods employed were the same as the ones of Corrêa et al. $(2014,2018)$ and Passos et al. (2018). Because individuals (and specially the smaller ones) are hard to identify through only the general morphology, some of their sclerites were extracted from the trunk by using fine needles, and then placed on slides, air-dried and covered with Entellan and a cover slip for permanent preparations; these slides are also deposited in the respective collections.

Apart from the Brazilian specimens, samples of S. megaradulatus analyzed by Scheltema (1981) from North Carolina, United states, deposited in the Museum of Comparative Zoology (MCZ), Harvard University, Cambridge, MA, United states, as well as the samples of this species and of S. chilensis deposited in the American Museum of Natural History (AMNH), New York, United states, were observed. Further, while an analysis was performed in the MCZ and in the National Museum of Natural History, Smithsonian Institution (USNM) (Miranda et al., 2020), specimens identified as species of Scutopus were also searched in these molluscan collections.

To further investigate the potential distribution of the Scutopus species in the Atlantic, a species distribution model (SDM) was performed using MaxEnt 3.4.4.k (Phillips et al., 
2006), for the new species described herein, S. robustus and S. ventrolineatus. Scutopus megaradulatus was not included due to the few records available in literature $(<10)$. For the new species, a total of 33 records were used, based on the samples observed in this study. For S. robustus (24 records) and S. ventrolineatus (15 records), datasets of records were produced based on the literature (see Table 3); those of S. robustus from SalviniPlawen (1977) were not included as they are considered doubtful (Ivanov and Scheltema, 2001).

Environmental data were obtained from the Global Marine Environment Datasets (GMED) (Basher et al., 2018) with a resolution of $5^{\prime}$ (approx. $9.2 \mathrm{~km}$ near equator). As caudofoveates are benthic organisms, variables reflecting environment near the seabed were used, namely depth, slope, bottom temperature, primary productivity and bottom silicate. These variables had a weak to medium correlations $(r<0.7)$, calculated by the Pearson correlation in ENMTools 1.4.3 (Warren et al., 2010). To generate the model, 100,000 random background points were used, with a regularization multiplier of $1.75 \%$ of presence records were randomly chosen and used in the model training while the remaining $25 \%$ were used in the model testing. Also, the "fade by clamping" option was set to reduce prediction into areas with environmental conditions that were not found during model training, and 10 replicates using Bootstrap as "Replicated run type" (Basher and Costello, 2016). All other parameters were used as default. To test model goodness of fitting, the area under the curve operating characteristics was used (AUC). The potential distribution was computed as Cloglog. Later, with this the output, to define the Minimum Presence Threshold (MPT), "10 percentile training presence" threshold was used (MoruetaHolme et al., 2010). The final output rasters were classified in not suitable (below the MPT) and suitable (above MPT) areas.

\section{RESULTS}

Family Limifossoridae Salvini-Plawen, 1969

Genus Scutopus Salvini-Plawen, 1968

Type species: Scutopus ventrolineatus Salvini-Plawen, 1968 by original designation.

Remarks: Salvini-Plawen (1968) characterized S. ventrolineatus by its long, undivided, cylindrical body which coils up spirally when it is disturbed, its radula composed by multiple rows of paired teeth, each tooth bearing median denticles, an undivided or homogeneous, post-oral shield, and the presence of a long midgut sac or digestive gland, and by its sclerites that ventrally are positioned in a divergent way forming a clear external ventral sutural line. Later, Salvini-Plawen (1975) and Ivanov (1981) highlighted that the characters of the oral shield and the radula are typical of Scutopus species. The new species described herein has these main characteristics, as shown below.

Scutopus variabilis sp. nov. Passos, Corrêa and Miranda (Figures 1-6, 8)

LSID: urn:lsid:zoobank.org:act:A734DD68-A074-42FB-A9C4 -A1DFAD68D4B9

\section{Type Material}

Holotype: ZUEC APL 277, sta HAB6-C7-R2(2-5) $\left(22^{\circ} 59^{\prime} 52.609^{\prime \prime} \mathrm{S}, 40^{\circ} 47^{\prime} 45.008^{\prime \prime} \mathrm{W}\right)$ (Brazil - off Rio de Janeiro State), "Habitats" Project coll., 30/vi/2008, 689.4 m; entire individual (Figure 1A) plus one slide with its sclerites. Total length: $11 \mathrm{~mm}$; anterium plus neck: $2 \mathrm{~mm}$; trunk: $8 \mathrm{~mm}$; posterium: $1 \mathrm{~mm}$.

Paratypes: All collected in the southeastern and southern Brazilian coasts, from off States of ES, RJ, SP, PR, and RS; 188 specimens in 71 samples (Table 1).

Type locality. Off Rio de Janeiro, $40^{\circ} 47^{\prime} 45.008^{\prime \prime} \mathrm{W}$, $22^{\circ} 59^{\prime} 52.609^{\prime \prime} \mathrm{S}, 689.4 \mathrm{~m}$.

Non-type material. All collected in the southeastern Brazilian coasts, from off States of ES and RJ; 153 specimens in 61 samples (Supplementary Table 1).

Diagnosis. Body long, slender, up to $14 \mathrm{~mm}$ in length, often contorted, almost uniform in diameter; in most specimens divided in three parts: an anterior part separated by a main collar from a median part, and a slightly tapered posterior part. Oral shield post-oral, ventral to the mouth. Midventral suture line present. Two main types of sclerites: one elongated, with lateral margins slightly concave in medial portion, with base wider and about a half of the blade length, and another shorter, triangular, base and blade with continuous straight lateral margins; in both, blade ornamented with a central keel and weak adjacent longitudinal grooves. Radula distichous, with up to eight transversal rows of heavily sclerotized teeth (except for the two most proximal pairs); each tooth inwardly curved, with 12-16 small median bent denticles present in all the extension of the concave, inner margin.

Etymology. The name variabilis refers to the variable form and color exhibited by the specimens of this species.

\section{Description}

\section{External Appearance}

Body whitish to brownish in color, opaque in most adult specimens; cylindrical in form, long, slender, up to $14 \mathrm{~mm}$ in length, often contorted; almost uniform in diameter, up to $0.9 \mathrm{~mm}$ in width (Figures 1, 2A-D,G). Body almost homogeneous throughout its length, but in most specimens with three externally distinguishable parts: an anterior, separated by a main collar from a median part (Figures 1B,F,I,K,M,O, 2A$\mathbf{C}, \mathbf{G}$ ), and a slightly tapered posterior part (Figures $\mathbf{1 A}, \mathbf{C}, \mathbf{K}$ ). Anterior part whitish to transparent, composed by a sometimes protruded peribuccal region (or anterium) (Figures 1C,I, 2A,B) and a short foregut region (neck or prothorax) (Figures $\mathbf{1 A}, \mathbf{H}$, 2A,B). Median part (trunk or metathorax) dark brown, reflecting the presence of the midgut internally; a secondary collar sometimes present separating this median part in two regions: an anterior short midgut region, and a long posterior midgut sac region (Figure 1H). Posterior part short, composed by a narrower, transparent prepallial region and a pallial region which is often slightly inflated; secretions of the animal occur over the sclerites, giving a reddish color to the entire posterior part, or more often around the pallial region or in the center of the posterior end (Figures $\mathbf{1 A}, \mathbf{B}, \mathbf{D}-\mathbf{F}, \mathbf{I}, \mathbf{K})$. When the peribuccal 


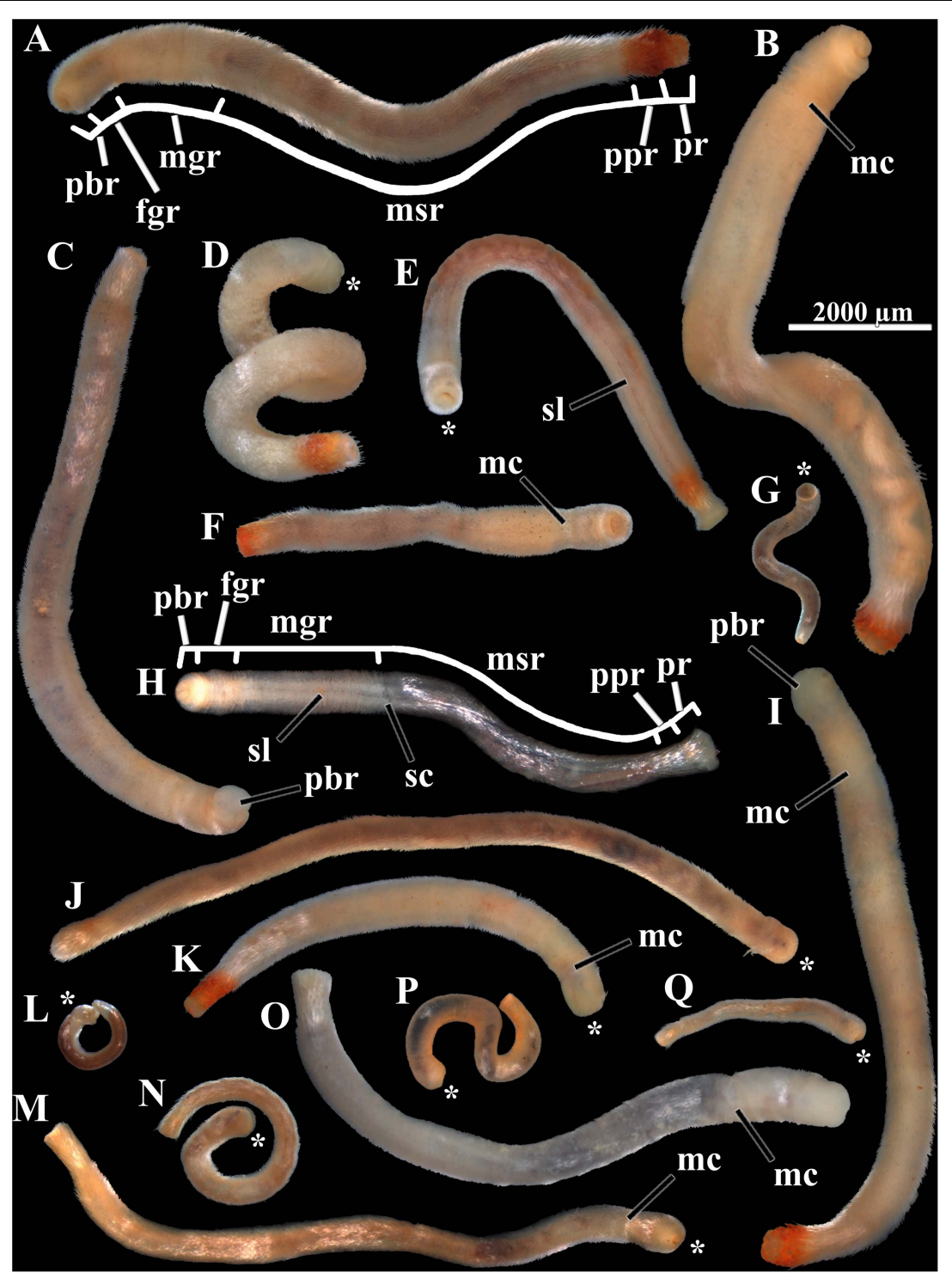

FIGURE 1 | Scutopus variabilis sp. nov. Photomicrographs under stereomicroscope of specimens of different sizes showing their variable body form and color (all in same scale). The body regions are shown in (A) (holotype) and (H), (B) and (D) had their soft parts dissolved for the extraction of their radulas [which are shown in Figures $4 \mathbf{A}, \mathbf{E}$, respectively and of their sclerites from the different body regions. The peribuccal region is protruded in (C) and (I). The midventral suture line is visible in (E) and (H); the main collar in (B), (F), (I), (K), (M), and (O); and the secondary collar in (H). The asterisks in (D), (E), (G), (J-N), (P), and (Q) show the anterior end. fgr - foregut region; $\mathrm{mc}$ - main collar; mgr - midgut region; msr - midgut sac region; pbr - peribuccal region; ppr - prepallial region; pr - pallial region; sc secondary collar; sl - midventral suture line. Voucher numbers: (A) - ZUEC APL 277, (B) - ZUEC APL 285, (C) - ZUEC APL 287, (D) - ZUEC APL 284, (E) - ZUEC APL 279, (F) - ZUEC APL 282, (G) - ZUEC APL 306, (H) - ZUEC APL 298, (I) - ZUEC APL 286, (J) - MZSP 154099, (K) - ZUEC APL 286, (L) - ZUEC APL 326, (M) - MNRJ 23638, (N) - ZUEC APL 331, (O) - ZUEC APL 291, (P) - ZUEC APL 311, (Q) - ZUEC APL 283.

region is swollen, the ventral oral shield is visible (Figure 2E); when contracted, the oral shield contracts in its midline, appearing divided in two lateral parts (bipartite) (Figures 2F,H). Sclerites uniformly cover all the surface of the body, except ventrally, where they are positioned in a divergent way, forming a midventral suture line along the foregut region and all the midgut and midgut sac regions (Figures 1E, 2A-C,G). Variations in color and form occur among specimens of the same size, and among juveniles and adults; the main collar is not visible in many individuals and so they appear to have an undivided body (Figure 1J); smaller individuals tend to be slender, transparent, with the main collar and the ventral suture line quite indistinguishable (Figures $\mathbf{1 G}, \mathbf{L}, \mathbf{N}, \mathbf{P}, \mathbf{Q}$ ).

\section{Sclerites}

Adpressed to the mantle, positioned parallel to the longitudinal body axis, except in the midgut region, where they are bristling in some specimens (Figures 2C,G). In the peribuccal region flat, small, $50 \mu \mathrm{m}$ long $\times 25 \mu \mathrm{m}$ wide, drop-shaped, without waist, pointed at the tip, smooth (Figure $\mathbf{3 A}$ ); or triangular, 


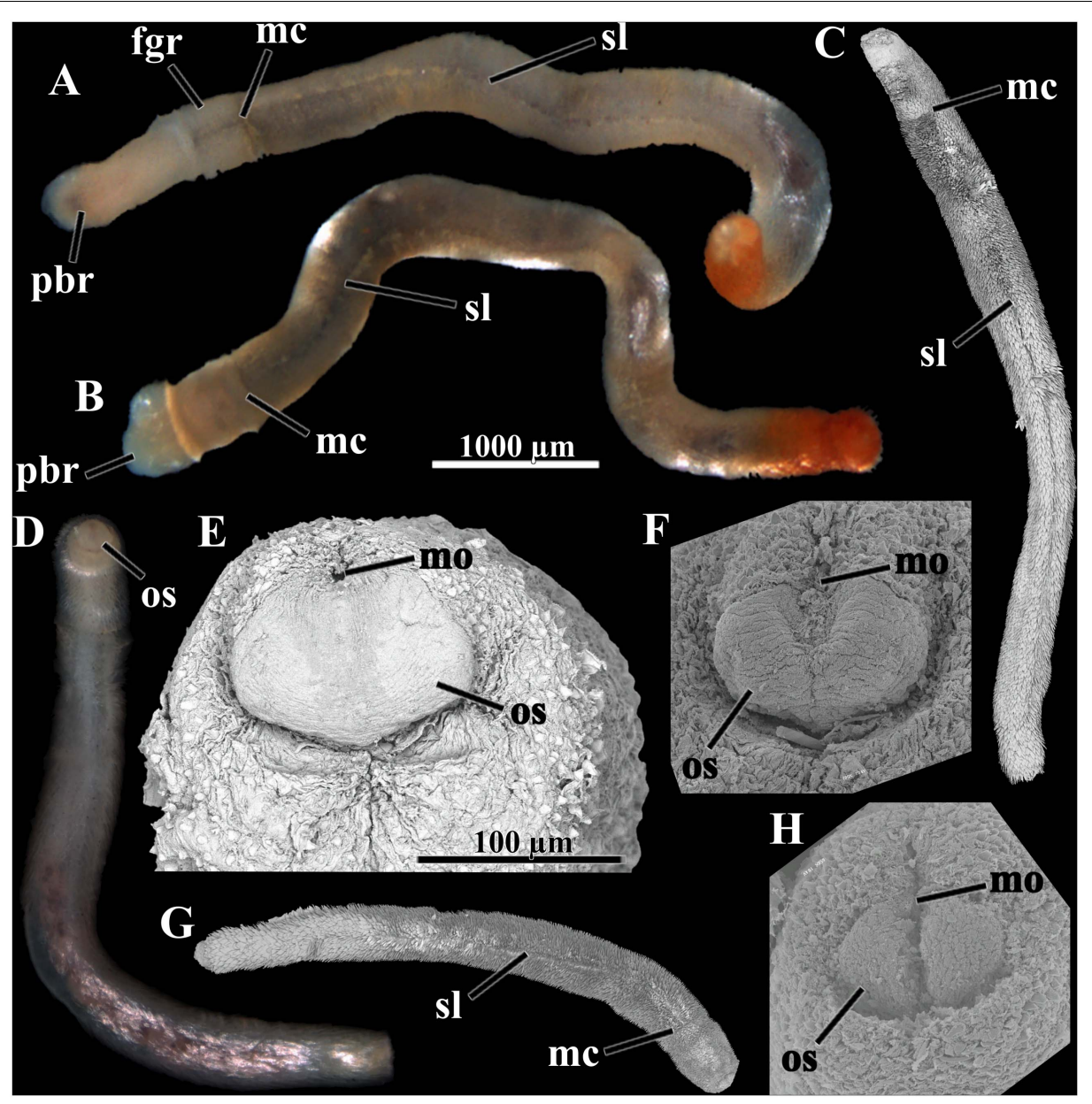

FIGURE 2 | Scutopus variabilis sp. nov. Photomicrographs under stereomicroscope [(A), (B), and (D)] and SEM (C,E-H); (A-D) and (G) are in same scale, as are $(\mathbf{E}),(\mathbf{F})$ and $\mathbf{( H )}$. (E), (F), and $\mathbf{( H )}$ are a detail of the anterior end, showing the oral shield in different degrees of contraction; $(\mathbf{E})$ is the oral shield of $(\mathbf{D})$, which is in the most relaxed state; in (F) it is in an intermediary state and in $(\mathbf{H})$ it is strongly contracted appearing bipartite. The peribuccal region is protruded in $(\mathbf{A})$ and $(\mathbf{B})$. The midventral suture line and the main collar are visible in (A-C) and $\mathbf{G}$. fgr - foregut region, mc - main collar, mo - mouth, os - oral shield, pbr - peribuccal region, sl midventral suture line. Voucher numbers: (A,B) - MNRJ 23639, (C) - ZUEC APL 306, (D) - ZUEC APL 280, (E) - ZUEC APL 280, (F) - ZUEC APL 314, (G) - ZUEC APL 312, (H) - ZUEC APL 299.

longer, $86 \mu \mathrm{m}$ long $\times 36 \mu \mathrm{m}$ wide, with a distinct waist, base longer and wider than blade, blade ornamented with a central keel and pointed at the tip, basal margin almost straight (Figure 3B). In the foregut region $118 \mu \mathrm{m}$ long $\times 28 \mu \mathrm{m}$ wide, with a weak waist, base shorter but wider than blade, blade ornamented by a median keel sided by weak longitudinal grooves, basal margin almost straight (Figure 3C). In the midgut region, triangular, $95 \mu \mathrm{m}$ long $\times 39 \mu \mathrm{m}$ wide, without waist, base and blade with continuous straight lateral margins, blade ornamented by a central keel (Figure 3D); or elongated, $131 \mu \mathrm{m}$ long $\times 56 \mu \mathrm{m}$ wide, lateral margins slightly concave in medial portion, base wider and about a half of the blade length, blade ornamented with a keel and weak adjacent longitudinal grooves, basal margin slightly notched (Figure $3 \mathrm{E}$ ). In midgut sac region, two dominants: one with the same shape as the latter, up to $162 \mu \mathrm{m}$ long $\times 56 \mu \mathrm{m}$ wide (Figure 3F), and another, longer, with narrower base, up to $194 \mu \mathrm{m}$ long $\times 45 \mu \mathrm{m}$ wide
(Figure 3G); a third type, drop-shaped, less abundant, shorter, $86 \mu \mathrm{m}$ long $\times 45 \mu \mathrm{m}$ wide (Figure $3 \mathrm{H}$ ). Midventral suture line with two types: one elongated, base wider, one third of the total length, blade with parallel lateral margins (Figure 3I), and other tapered in medial portion, with base weakly wider than blade (Figure 3J), both up to $193 \mu \mathrm{m}$ long $\times 37 \mu \mathrm{m}$ wide, with a keel and longitudinal grooves in blade, and a rounded basal margin. Prepallial region with two very elongated types: one lanceolate, with continuous base and blade lateral margins, $262 \mu \mathrm{m}$ long $\times 62 \mu \mathrm{m}$ wide (Figure $3 \mathrm{~K}$ ), and another narrower, with short base and long blade, parallel margins in most of its length, $287 \mu \mathrm{m}$ long $\times 37 \mu \mathrm{m}$ wide (Figure $3 \mathrm{~L}$ ); both with several grooves on blade and rounded basal margin. In pallial region: spatulate, narrow, short, $73 \mu \mathrm{m}$ long $\times 11 \mu \mathrm{m}$ wide, with a pointed smooth blade and wider base, present in the posterior margin of pallial region (Figure 3M); and large, $390 \mu \mathrm{m}$ long $\times 48 \mu \mathrm{m}$ wide, needle shaped or wider at base, with a 


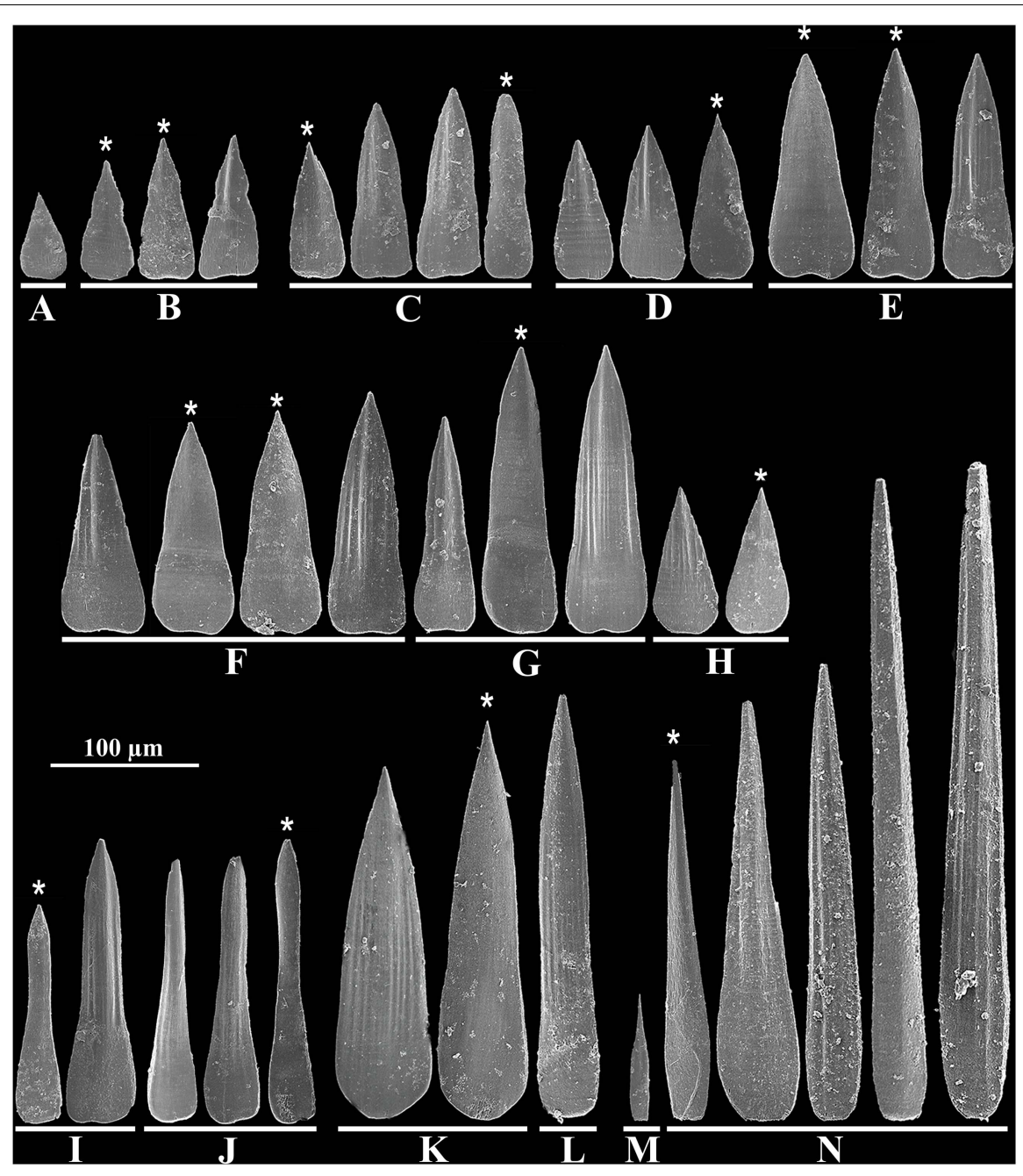

FIGURE 3 | Scutopus variabilis sp. nov. SEM photomicrographs of isolated sclerites from the different body regions: (A), (B), peribuccal region; (C), foregut region; (D), (E), midgut region; (F-H), midgut sac region; (I), (J), midventral suture line; (K), (L), prepallial region; (M), (N), pallial region. The asterisks point out the sclerites shown from the side facing the body. All in same scale.

keel and longitudinal grooves on all along the base and blade (Figure $3 \mathrm{~N})$. All the sclerites have a smooth surface facing the body (Figure 3, asterisks).

\section{Radula}

Large and elongated, up to $1.2 \mathrm{~mm}$ long, distichous, with up to eight transversal rows of paired teeth, which are heavily sclerotized, except the two most proximal pairs (Figure 4A). Each tooth is inwardly curved, up to $790 \mu \mathrm{m}$ long $\times 385 \mu \mathrm{m}$ wide, with 12-16 small median bent denticles that are present along the whole extension of the concave, inner margin of the tooth (Figures 4B-E).

Bathymetric and geographical distribution: A total of 342 specimens distributed in 133 samples were examined, most of them (123 samples) obtained from the States of Espírito Santo and Rio de Janeiro by the "Habitats" and "Ambes" Projects (Figure 5). In this area, samplings were more intensive and occurred in a wide bathymetric range, and so the specimens of
S. variabilis sp. nov. were collected from 40 to $1300 \mathrm{~m}$, with 62 samples coming from the shelf waters (less than $200 \mathrm{~m}$ ). Ten samples were obtained from scattered points outside this area, proving that this species occurs all along the Brazilian southeastern and southern coasts; these samples were collected from only the continental shelf (less than $130 \mathrm{~m}$ depth) (Figure 6). The number of specimens per sample varies from 1 to 12 , but in most (98 samples) there are up to 3 three individuals. This species can be characterized as occurring in a wide bathymetric range, with a great abundance at the edge (140$200 \mathrm{~m}$ ) between the continental shelf and upper slope (Figure 5).

\section{Species Distribution Modeling}

For all the three analyzed species, the distribution model has a mean AUC $>0.996$ for the training and test data, with a standard deviation of 0.001 . The 10 percentile training presence threshold was $0.1167,0.3075$, and 0.4359 , for $S$. variabilis sp. nov., S. robustus, and S. ventrolineatus, respectively. The 


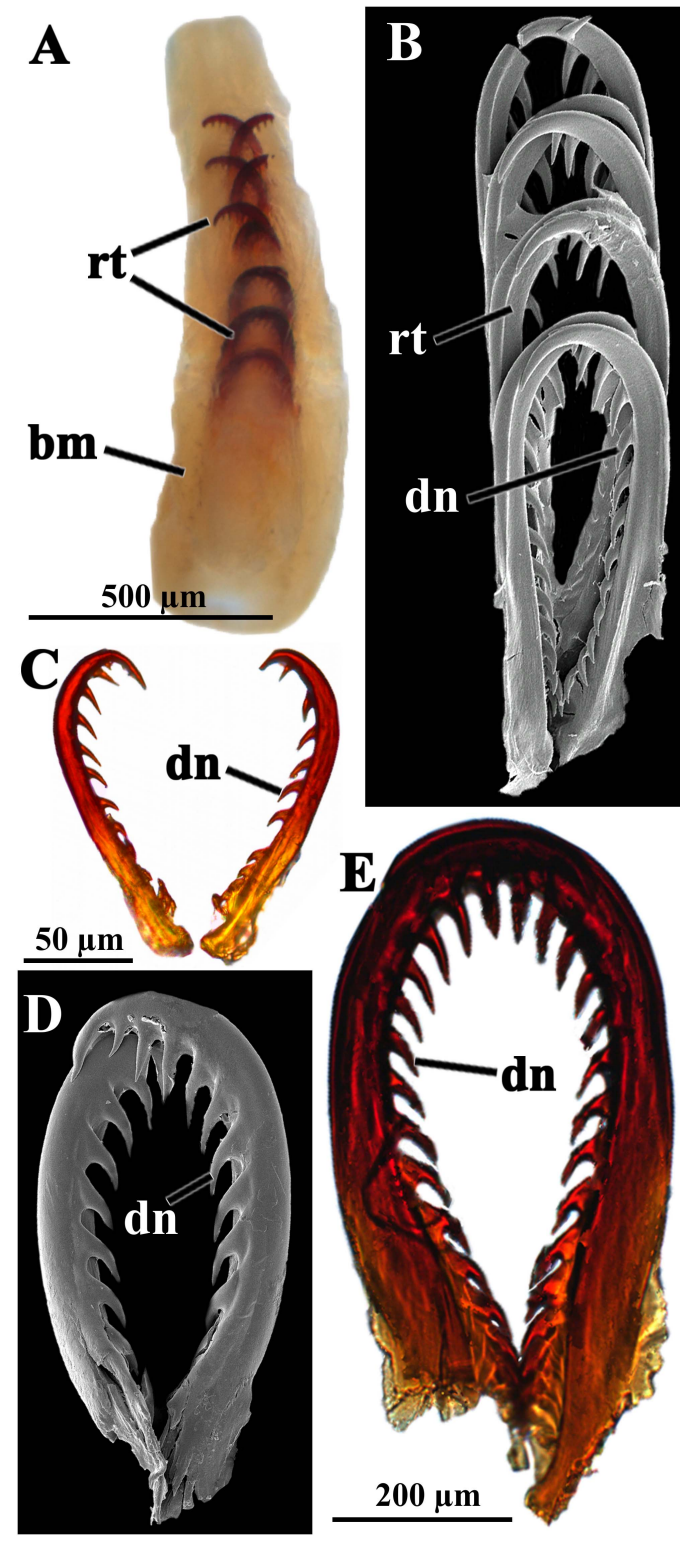

FIGURE 4 | Scutopus variabilis sp. nov. Photomicrographs under stereomicroscope (A), SEM [(B) and (D)] and light microscopy [(C) and (E)] of the radula. In (A) (ZUEC APL 284) the entire radula of the individual shown in the Figure 1D is viewed immersed in the buccal mass. In (B) (ZUEC APL 319) four pairs of radular teeth are viewed in detail, and isolated pairs in (C-E); in (C) (ZUEC APL 321) and (D) (ZUEC APL 319) the teeth were obtained from two small specimens (up to $4 \mathrm{~mm}$ in length), and in (E) (ZUEC APL 285) from the larger animal (about $11 \mathrm{~mm}$ ) shown in Figure $\mathbf{1}$ (B). (B-D) are in same scale. bm - buccal mass, dn - median denticles, rt - radular tooth.

environmental layer that most explained the potential habitat suitability of $S$. variabilis sp. nov. is depth, followed by bottom temperature (Table 2). Each of the other variables explained less than $10 \%$ of the habitat suitability. Depth and temperature had similar influences on the distribution of $S$. robustus (Table 2). Although depth had similar values of importance, for $S$. ventrolineatus silicates and primary productivity had relatively great importance in the final habitat suitability, with slope and temperature explaining less than $10 \%$ of habitat suitability (Table 2 ).

The generated maps show that main suitable areas of occurrence of $S$. variabilis sp. nov. are the Brazilian Southeastern and Southern coasts (Figure 7); the limits of distribution are the North of Espírito Santo in the north edge of this area, and the Chuí in the south. There were also some hotspots of suitability in Southern Caribbean Sea and a very narrow hotspot in the Brazilian Northern coast, east to the Amazon River mouth (States of Pará and Maranhão, Brazil). No suitability was found for S. variabilis sp. nov. in the Gulf of Mexico and in the Brazilian Northeastern coasts. In the Eastern Atlantic, points of suitability were found in Cape Verde and Angola Basins, in the Adriatic Sea (Albania) and in the area of the Suez Isthmus (Egypt).

Scutopus ventrolineatus was the species with the wider estimated distribution. The main suitable areas were between Southern Scandinavia and Britain, English Channel, Southwestern Ireland, Bay of Biscay, Iberian Peninsula, Strait of Gibraltar and Mediterranean of France (Figure 7). Wide suitable areas were found in Cape Verde, Guinea and Angola Basins in Africa. Outside the Eastern Atlantic, a continuous suitable area was found from Newfoundland to the North of Florida. Other areas were the Northern Gulf of Mexico, Tierra del Fuego, and Argentine Basin.

For $S$. robustus, the map shows that the main suitable areas are the Northwestern of Norway, Scotland, North of Ireland, South of Iceland, and Northern Lusitania, occurring in the outer part of West European Basin (Figure 7). In the Western Atlantic, suitable areas were found in Northeastern Falklands.

Through modeling, small areas of overlapping distribution of these species were detected (Figure 7). Scutopus ventrolineatus and $S$. robustus had the largest overlap in Southern Norway, and a small area occurred in the Iberian Basin. Scutopus variabilis sp. nov. had many islands of overlapping areas with $S$. ventrolineatus in Angola and Cape Verde Basins. No overlaps were found between $S$. robustus and $S$. variabilis sp. nov. or shared by all the three species.

\section{Comments on Other Examined Species of Scutopus}

Two lots of $S$. megaradulatus deposited in the AMNH collection were examined. One of them (AMNH 265347) was from the single sample listed by Salvini-Plawen (1972), which had two specimens when he originally described this species. Currently, this lot AMNH 265347 contains two small tubes: one bears the anteriormost body part of a specimen (the oral shield is visible) that lost some of its sclerites (Figures 8A,B); and the other has an incomplete animal (with its anterior body part missing, see detail in Figure 8C) which is the same illustrated in the original description of this species (compare Figure 8C with fig. 21 of Salvini-Plawen, 1972). The radula described by SalviniPlawen (1972) was surely extracted from the latter individual, which was in turn designated as the lectotype by Boyko and Sage (1996). The other lot (AMNH 265348) contains a fragment of the trunk, presumably from the midgut region (the bristling 


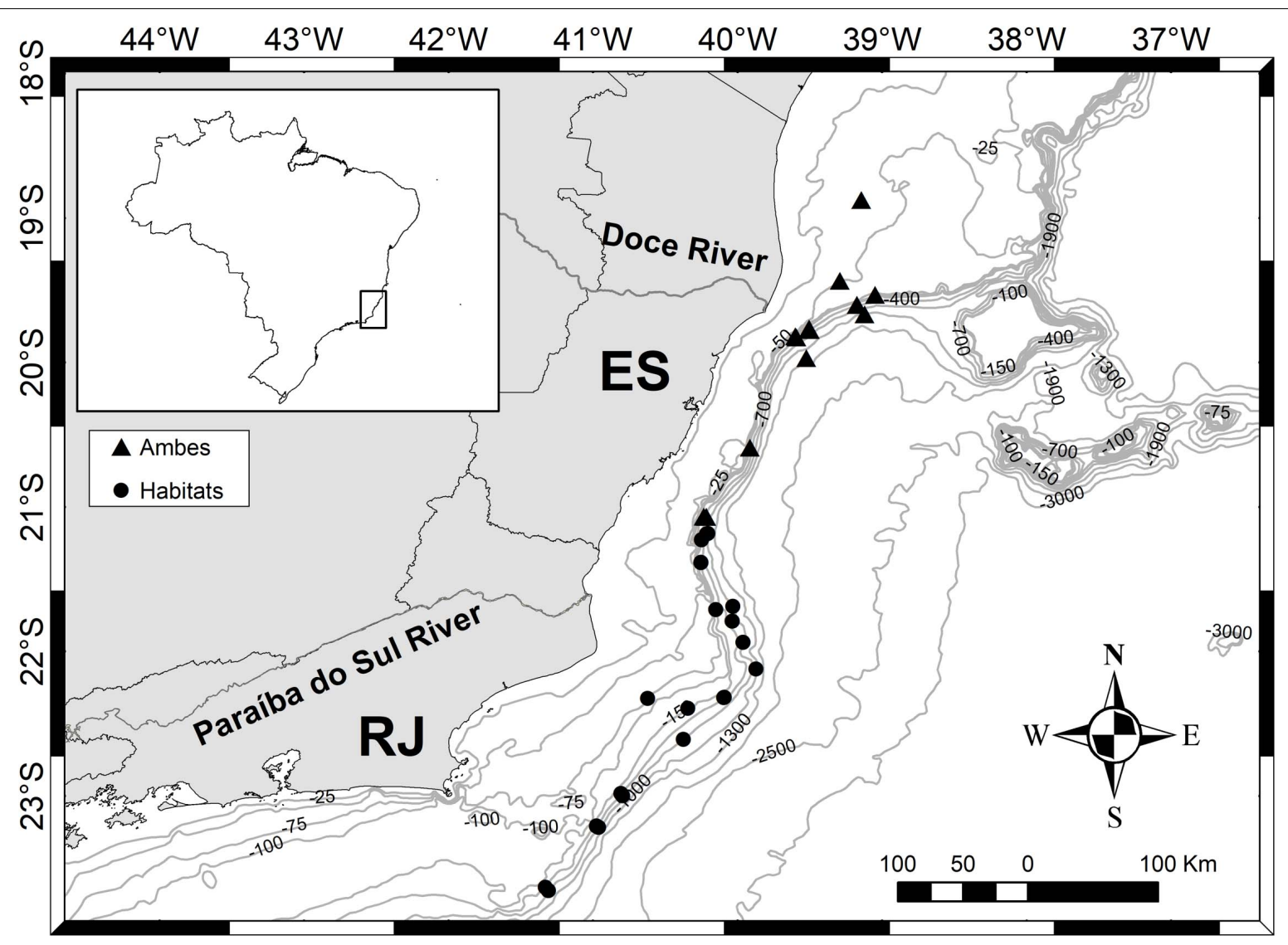

FIGURE 5 | Scutopus variabilis sp. nov. Sampling area of the "Habitats" (off Rio de Janeiro) and "Ambes" (off Espírito Santo) Projects showing the bathymetric distribution in the area of the Espírito Santo and Rio de Janeiro States.

sclerites are visible; Figure 8D) of one individual cited by Salvini-Plawen (1992) as a second examined sample collected in the same area of the Gulf of Darien, Caribbean Sea, at about $900 \mathrm{~m}$ depth, off Panama. Salvini-Plawen (1992) also referred to a third sample of $S$. megaradulatus which was obtained at 1861 meters depth off the western Cape coast, South Africa, but the place where it is deposited could not be tracked, and thus this single record of this species from the eastern Atlantic was not confirmed. Scheltema (1981) examined specimens of S. megaradulatus collected at $650 \mathrm{~m}$ depth off Cape Hatteras, and these compose the lot MCZ 396015.

Regarding $S$. chilensis, two lots deposited in the $\mathrm{AMNH}$ collection were examined, both with labels indicating that they were from the same sample collected in the Strait of Magellan, southern Chile, which was one of the three samples used by Salvini-Plawen (1972) for the description of this species; at that time, this sample contained two specimens and a type was not designated. Currently, the lot (AMNH 265349) has an individual which had its anterior and posterior parts dissected (Figure 8E), and it is not possible to affirm this is the same of the figure 26 of Salvini-Plawen (1972); the other (AMNH 265350 ) is a slide containing a hardly visible radula. They were designated by Boyko and Sage (1996) as the lectotype and paralectotype, respectively.
In the collection of the USNM, all the lots identified as Scutopus were analyzed, including the samples examined by Treece (1979) from the Gulf of Mexico, but they revealed to belong to species from other genera (Psilodens, for example). In South America, records of Scutopus spp. from Brazil were made by Rios (1994, as "Scutopus cf. megaradulatus"; and 2009, as "Scutopus sp. ”), and from Uruguay by Forcelli and Narosky (2015, as "Scutopus sp."). However, the samples on which they were based could not be found, and so these records are doubtful.

\section{DISCUSSION}

Scutopus has been traditionally classified in the family Limifossoridae, along with other two genera, Limifossor Heath, 1904 and Psilodens Salvini-Plawen (1977), whose species have a characteristic multiseriate distichous radula; the inclusion of a fourth genus, Metachaetoderma Thiele, 1913, is debated and unsolved (Salvini-Plawen, 1969; Ivanov, 1981). In Psilodens and Scutopus the body is slender, sometimes bearing an annular constriction separating an anterior (formed by peribuccal plus foregut regions) from the median body part, while species of Limifossor have stouter bodies without externally visible divisions. Apart from this, the radula of Psilodens and Scutopus 


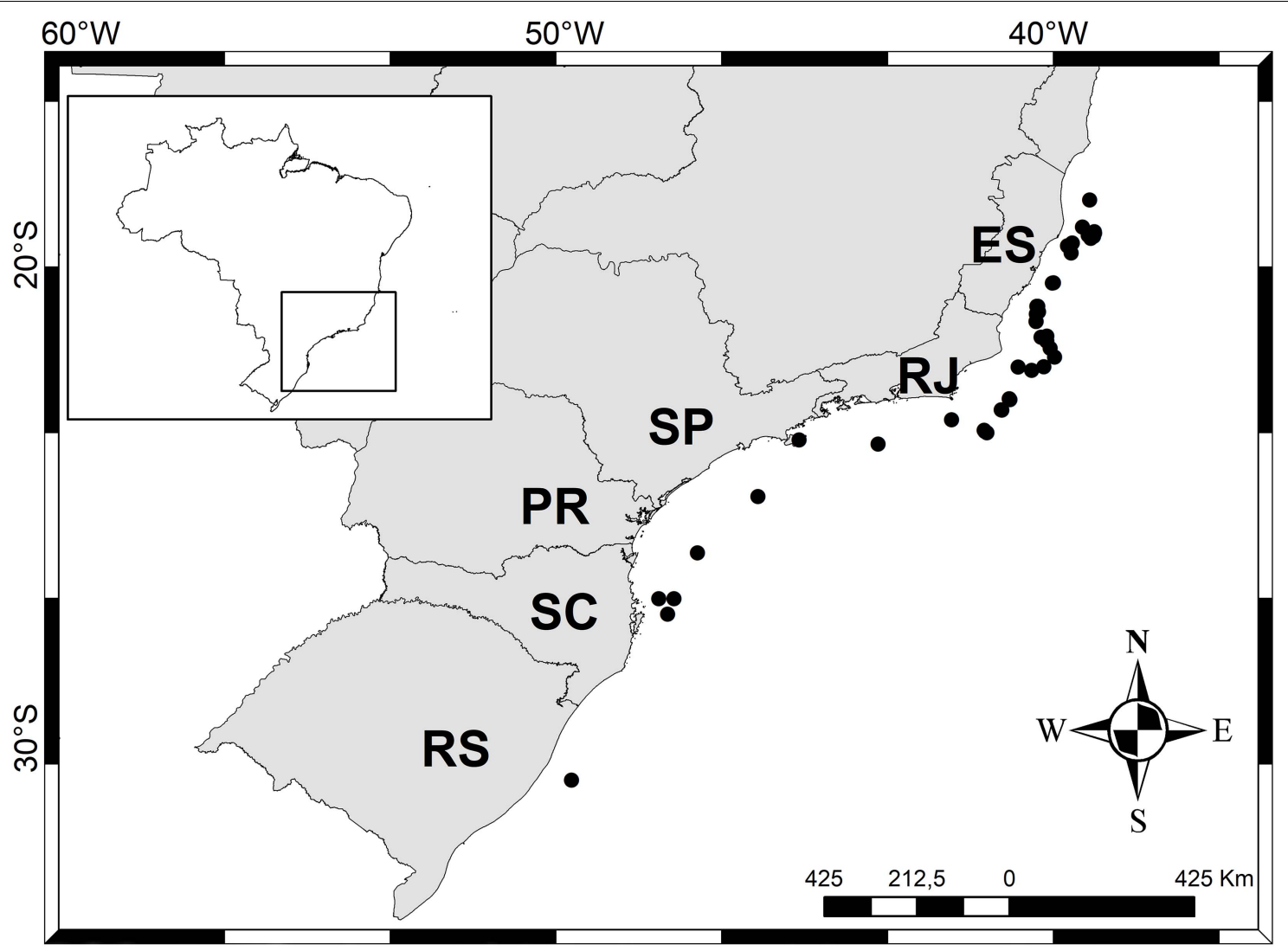

FIGURE 6 | Scutopus variabilis sp. nov. Distribution of this species along the States of the Southeastern and Southern Brazilian coasts.

is quite distinct from the one of Limifossor: in the former genera, each tooth is inwardly curved, like a sickle, the ones of Scutopus having a variable number of denticles distributed all along or in a part of the concave inner side of each tooth, while in Psilodens there are no denticles; in Limifossor each tooth consists of broad plates that bear a main lateral projection like a long hook-shaped stylet, and one or two small additional projections which form a jagged cutting inner edge (SalviniPlawen, 1968, 1977, 1992; Ivanov, 1981; Scheltema, 1981). Differences among these genera also occur in the shape of the oral shield, that is undivided in species of Scutopus and bipartite in Limifossor and Psilodens (Salvini-Plawen, 1968, 1977, 1992; Ivanov, 1981; Scheltema, 1981). To date there are five species of Limifossor and three of Psilodens, and together with the seven species of Scutopus they characterize the Limifossoridae as the less diverse family among the caudofoveate aplacophorans; its other valid families, Chaetodermatidae Théel, 1875 and Prochaetodermatidae Salvini-Plawen (1972), have 85 and 39 described species, respectively.

As in other genera of Caudofoveata, the species of Scutopus are distinguished by external characters of the body morphology in conjunction with more detailed characteristics of the sclerites and radula (Table 3). Therefore, the presence of the midventral suture line, the size, shape, and sculpture of the sclerites from the different body regions, as well as the number and position of denticles in each radula tooth, have been the main characters for description of its species (Table 3). All of them have a long body shape, most presenting an anterior collar separating the anterior from the median body part. With many specimens available for the present study, it was possible to observe that the fixed specimens of $S$. variabilis sp. nov. exhibit a great variation in the form of the body caused by contractions of the musculature, being often contorted in different ways, narrowed and modified in its length:width proportions and in the relative sizes of the different body regions (specially the peribuccal, the foregut and the midgut regions). The anterior main collar is not visible in many specimens, this being particularly frequent in young individuals. For this reason, many animals can easily be confounded with other co-occurring caudofoveates, such as two undescribed species of Psilodens and Falcidens; in these cases, extraction of the sclerites is desirable for a more definite identification.

The midventral line is present in most species of Scutopus (Salvini-Plawen, 1968, 1972, 1975; Osorio, 1981; Saito and Salvini-Plawen, 2014), but was characterized as inconspicuous in S. megaradulatus (Salvini-Plawen, 1972), being absent only in S. robustus (Salvini-Plawen, 1970, 1972). Apart from this genus, the midventral line has been also recorded in Falcidens sagittiferus Salvini-Plawen (1968) (Ivanov et al., 2009) and in Psilodens balduri Mikkelsen and Todt (2014) (Mikkelsen and Todt, 2014), 


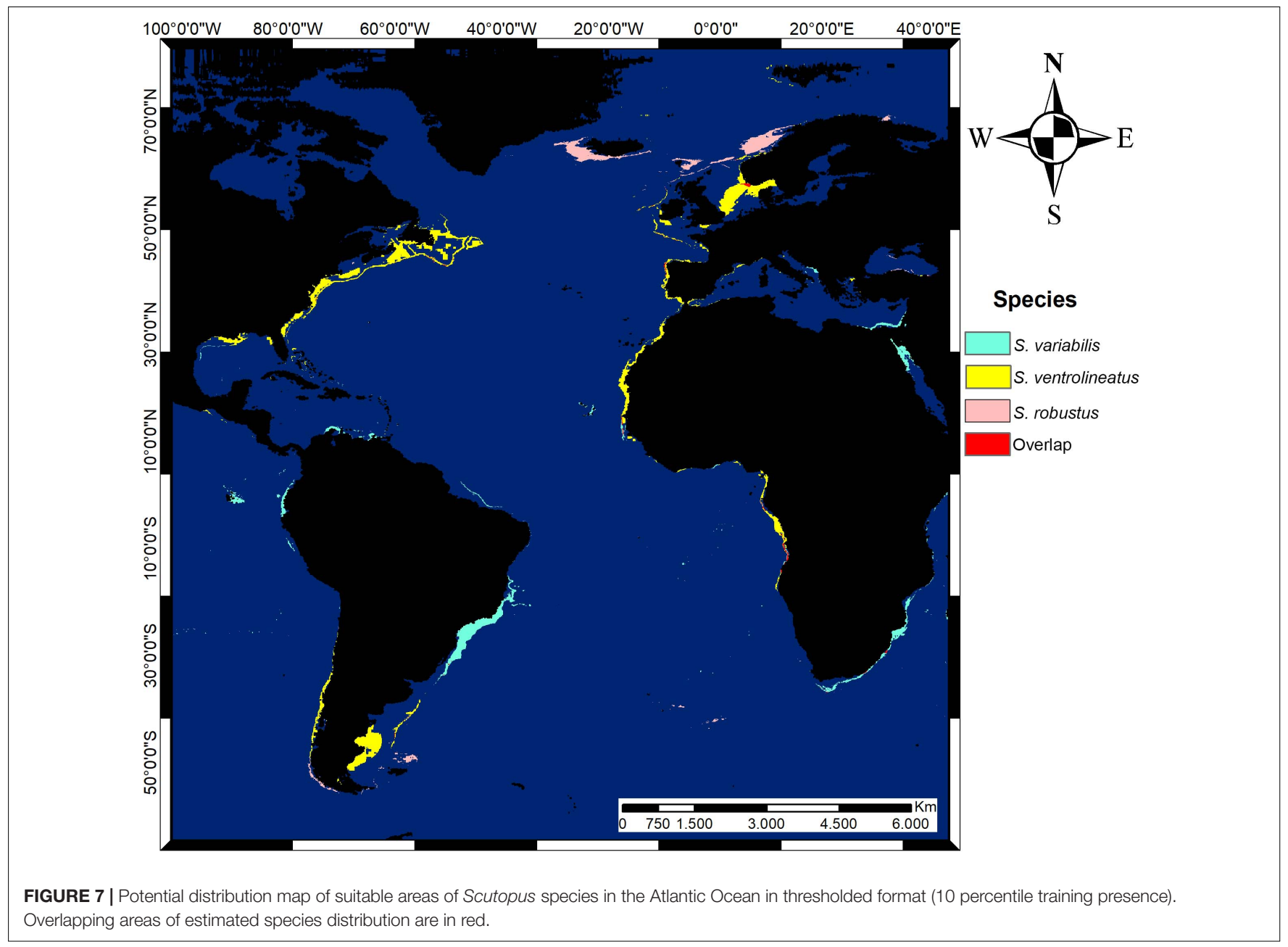

both on the anterior trunk, exhibiting characteristic adjacent sclerites, distinct in shape and size from the ones of the other body parts. In the Brazilian new species, the suture line is well visible in most specimens, especially by SEM, and has two types of adjacent sclerites, one with a wider base and longer blade that has almost parallel sides, and another which is narrower in the medial portion. This latter type was also observed in other species of Scutopus, such as S. ventrolineatus, S. chilensis, S. schanderi, and S. hamatanii (Salvini-Plawen, 1968, 1972; Saito and Salvini-Plawen, 2014), but not in S. megaradulatus (Salvini-Plawen, 1972).

In past times, SEM was a tool only for a general characterization in Caudofoveata (Scheltema, 1985, 1997; Scheltema et al., 1994), but more recently it has been used to furnish more complete descriptions (Schander et al., 2006; Ivanov et al., 2009; Mikkelsen and Todt, 2014; Saito, 2020), becoming a routine technique for the studies of the Brazilian species (Corrêa et al., 2014, 2018; Passos et al., 2018). In such way, apart from the general morphology of the animals, important characteristics of the oral shield, radula and sclerites can be observed. Regarding species of Scutopus, the sclerites are variable in form and size in the different body parts, there being dominant trunk sclerites which are important for the distinction of its species (Figure 9). Among them, S. variabilis sp. nov. is the first to have its sclerites described by SEM, with two dominant types observed in the median part: one elongated with lateral margins slightly concave in medial portion, and another longer, with narrower base. These are distinct from the ones of $S$. megaradulatus, in which they are slender and have parallel margins in the blade (Salvini-Plawen, 1972), and from the ones of S. schanderi, where they have an oar-blade shape (Saito and Salvini-Plawen, 2014). Some of the sclerites of $S$. ventrolineatus, S. robustus, S. chilensis, and $S$. hamatanii are like the ones of $S$. variabilis sp. nov., but in those species, there are dominant drop-shaped or lanceolate sclerites (Salvini-Plawen, 1968, 1972, 1975; Saito and Salvini-Plawen, 2014). The longitudinal sculpture of the sclerites appears to be also an important distinctive character: in S. variabilis sp. nov. the trunk sclerites have a main ridge and weak adjacent grooves in the blade, like in S. megaradulatus and S. schanderi, while in all other species there is only a main ridge, which appears to be more restricted to the distal end of the blade in S. ventrolineatus, S. robustus, and S. chilensis.

The present work also furnishes SEM images of the radula of a Scutopus species, a caudofoveate genus in which each species 


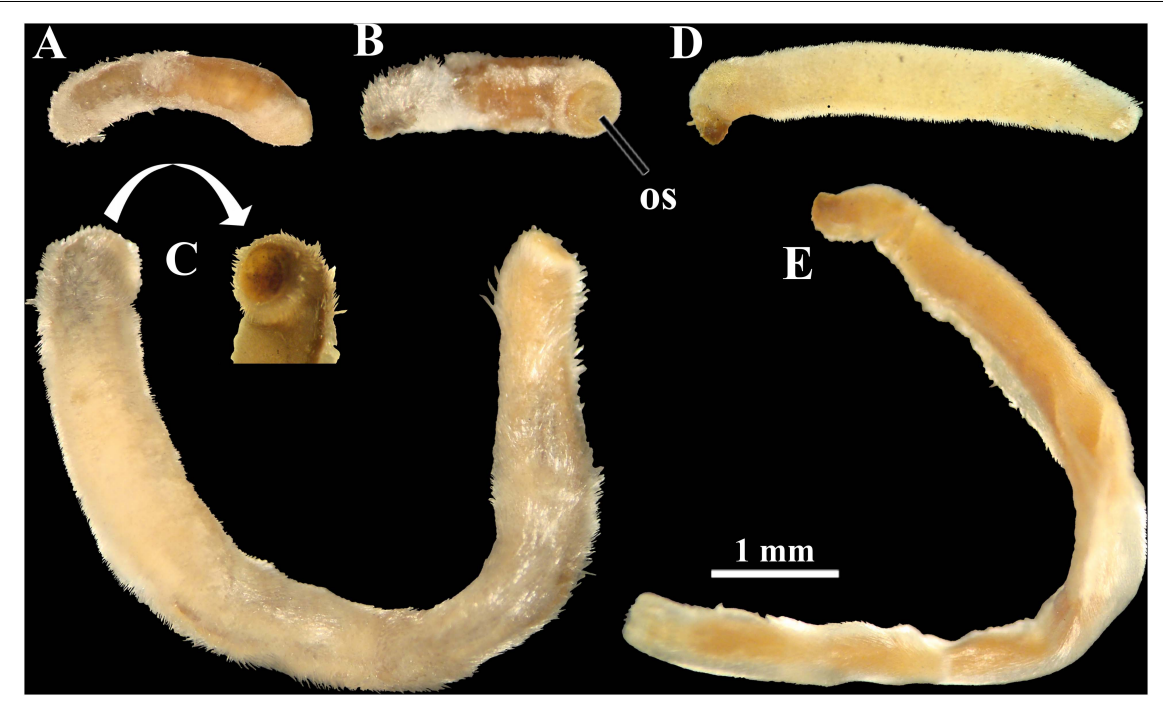

FIGURE 8 | Photomicrographs under stereomicroscope of examined lots of Scutopus megaradulatus (A-D) and S. chilensis (E). (A-C), AMNH 265347: this lot contains two tubes, one with the anteriormost body part [(A), (B), in right lateral and ventral views, respectively; the oral shield is visible in (B)], and another with a dissected specimen (C) which has its anterior end missing (viewed in detail); note that this latter specimens is the same as the one illustrated by Salvini-Plawen (1972: fig. 21) (although he photographed it from the opposite left side). (D), AMNH 265348, a fragment of the trunk (probably from the midgut region), shown from the left side. (E), AMNH 265349, viewed from the left side. All in same scale. os - oral shield.

has a characteristic number of rows of radular teeth, which in turn are strengthened by different degrees of sclerotization and bear a number of median denticles (Table 3, Figure 9). In S. variabilis sp. nov., the radula is heavily sclerotized and has eight pairs of teeth, characters that are similar to S. robustus, S. megaradulatus, and S. schanderi (up to ten rows), and different from S. ventrolineatus, S. chilensis, and S. hamatanii, in which teeth are more numerous (more than 10 rows) and weakly sclerotized. The median denticles are more variable, but in those heavily sclerotized radulas they tend to occur in a higher number (12-22 denticles) and all along the inner margin of the teeth, while in the radulas with weak sclerotization the teeth bear a lower number of denticles (less than 11; except S. chilensis). In these latter cases, the denticles are proximally positioned, leaving a distal hook. Interestingly, these radular differences reflected in ecological characteristics found in species distribution modeling, as, excluding depth, S. robustus and S. variabilis sp. nov. were influenced by bottom temperature, while $S$. ventrolineatus were more influenced by silicate and primary productivity. These may reflect unknown interactions between the characteristics of the radula and the environment, like the advantage of one type of radula in one environment over another due to food availability, or perhaps one type of radula may be easier to produce in environments with higher concentration of silicate. Further studies are necessary to clarify if this radular and ecological variability may represent different genera.

Regarding the geographical and bathymetric distribution, patterns exhibited by the different species of Scutopus appear to be distinct among European and non-European representants, although clear and definite figures are probably blurred by sampling bias. S. ventrolineatus and $S$. robustus are well known from Scandinavia, Western Europe and the Mediterranean Sea (Salvini-Plawen, 1968, 1970, 1972, 1975, 1977; Ivanov and Scheltema, 2001, 2014; Mikkelsen and Todt, 2014; Señaris et al., 2017), and were also investigated in more detail in relation to aspects of their natural history (Salvini-Plawen, 1968), anatomy (Scheltema, 1981; Scheltema et al., 1994), larval morphology (Salvini-Plawen, 1990, 2003), and molecular biology (Osca et al., 2014; Mikkelsen et al., 2019). Scutopus ventrolineatus was recorded as abundant species in some places of the Nowergian Sea (Salvini-Plawen, 1975; Todt, 2013) and apart from European waters, it occurs in the Southwestern Indic Ocean (off Durban) (Salvini-Plawen, 1972), but its supposed distribution all along the eastern African coast has not been noticed. So, at least one of these European species (S. ventrolineatus) seems to be generally characterized as having wide geographical and bathymetric distributions.

The wide recorded distribution of $S$. ventrolineatus was reinforced by the species distribution modeling, through which suitable areas were found in the Western African coast, in Cape Verde, Guinea and Angola Basins. Although Prochaetodermatidae is well known from West Africa (Scheltema and Ivanov, 2000), records of limifossorids are still lacking for these areas and thus more surveys and studies are necessary to understand the real diversity of caudofoveates in this region. The suitability in North American coast and Gulf of Mexico for $S$. ventrolineatus deserves future investigations. These areas were extensively explored, S. megaradulatus was already recorded from North Carolina (Scheltema, 1981), but this species is morphologically related with other Scutopus, like S. robustus and $S$. variabilis sp. nov. In the Gulf of Mexico, the recorded limifossorids do not belong to Scutopus. The suitability found in Tierra del Fuego and Falklands for S. ventrolineatus and 
TABLE 1 | Scutopus variabilis sp. nov. Paratype samples.

\begin{tabular}{|c|c|c|c|c|c|c|c|}
\hline Catalog No. & State & Station & Collector & Coordinates & Depth (m) & Date & Content \\
\hline ZUEC APL 278 & RJ & HAB4-CANG7-R3(5-10) & Habitats & $21^{\circ} 56^{\prime} 11.264^{\prime \prime} \mathrm{S}, 39^{\circ} 57^{\prime} 43.702^{\prime \prime} \mathrm{W}$ & 712.6 & $28 / v / 08$ & $1 \mathrm{spm}$ \\
\hline ZUEC APL 279 & RJ & HAB6-A7-R1(2-5) & Habitats & $23^{\circ} 39^{\prime} 20.061^{\prime \prime} \mathrm{S}, 41^{\circ} 18^{\prime} 30.264^{\prime \prime} \mathrm{W}$ & 693.7 & 23/vi/08 & 4 spms +1 slide with sclerites +1 stub with 1 spm \\
\hline ZUEC APL 280 & RJ & HAB6-A7-R3(2-5) & Habitats & $23^{\circ} 39^{\prime} 19.981^{\prime \prime} \mathrm{S}, 41^{\circ} 18^{\prime} 30.534^{\prime \prime} \mathrm{W}$ & 732.9 & 25/vi/08 & 1 stub with $1 \mathrm{spm}$ \\
\hline ZUEC APL 281 & RJ & HAB6-B7-R3(2-5) & Habitats & $23^{\circ} 13^{\prime} 2.006^{\prime \prime} \mathrm{S}, 40^{\circ} 57^{\prime} 36.765^{\prime \prime} \mathrm{W}$ & 724.6 & 28/vi/08 & 2 spms +2 slides with sclerites \\
\hline ZUEC APL 282 & RJ & HAB6-B7-R3(5-10) & Habitats & $23^{\circ} 13^{\prime} 2.006^{\prime \prime} \mathrm{S}, 40^{\circ} 57^{\prime} 36.765^{\prime \prime} \mathrm{W}$ & 724.6 & 28/vi/08 & 1 spm +1 slide with sclerites \\
\hline ZUEC APL 283 & RJ & HAB6-C7-R1(2-5) & Habitats & $22^{\circ} 59^{\prime} 51.839^{\prime \prime} \mathrm{S}, 40^{\circ} 47^{\prime} 42.838^{\prime \prime} \mathrm{W}$ & 710.1 & 29/vi/08 & $1 \mathrm{spm}+1$ slide with sclerites \\
\hline ZUEC APL 284 & RJ & HAB6-C7-R1(5-10) & Habitats & $2^{\circ} 59^{\prime} 51.839^{\prime \prime} \mathrm{S}, 40^{\circ} 47^{\prime} 42.838^{\prime \prime} \mathrm{W}$ & 710.1 & 29/vi/08 & 1 stub with 6 radular teeth +6 stubs with sclerites \\
\hline ZUEC APL 285 & RJ & HAB6-C7-R2(2-5) & Habitats & $22^{\circ} 59^{\prime} 52.609^{\prime \prime} \mathrm{S}, 40^{\circ} 47^{\prime} 45.008^{\prime \prime} \mathrm{W}$ & 689.4 & 30/vi/08 & $\begin{array}{l}2 \text { spms + } 1 \text { slide with sclerites + } 1 \text { slide with } \\
\text { radula }+6 \text { stubs with sclerites }\end{array}$ \\
\hline ZUEC APL 286 & RJ & HAB6-C7-R3(2-5) & Habitats & $22^{\circ} 59^{\prime} 52.279^{\prime \prime} \mathrm{S}, 40^{\circ} 47^{\prime} 45.398^{\prime \prime} \mathrm{W}$ & 686.1 & 01/vii/08 & 4 spms +3 slides with sclerites \\
\hline ZUEC APL 287 & RJ & HAB6-CANAC7-R2(2-5) & Habitats & $21^{\circ} 47^{\prime} 26.614^{\prime \prime} \mathrm{S}, 40^{\circ} 2^{\prime} 13.765^{\prime \prime} \mathrm{W}$ & 752.5 & 06/vii/08 & $1 \mathrm{spm}+1$ slide with sclerites \\
\hline ZUEC APL 288 & RJ & HAB6-D7-R2(2-5) & Habitats & $22^{\circ} 36^{\prime} 27.325^{\prime \prime} \mathrm{S}, 40^{\circ} 22^{\prime} 29.335^{\prime \prime} \mathrm{W}$ & 700 & 15/vii/08 & $1 \mathrm{spm}$ \\
\hline ZUEC APL 289 & ES & HAB6-17-R1(2-5) & Habitats & $21^{\circ} 11^{\prime} 12.183^{\prime \prime} \mathrm{S}, 40^{\circ} 12^{\prime} 52.020^{\prime \prime} \mathrm{W}$ & 693.9 & 17/vii/08 & 2 spms +2 slides with sclerites \\
\hline ZUEC APL 290 & RJ & HAB7-C6-R1(5-10) & Habitats & $22^{\circ} 59^{\prime} 1.179^{\prime \prime} \mathrm{S}, 40^{\circ} 48^{\prime} 24.830^{\prime \prime} \mathrm{W}$ & 399.7 & 04/vii/08 & $1 \mathrm{spm}$ \\
\hline ZUEC APL 291 & ES & HAB7-17-R3(2-5) & Habitats & $21^{\circ} 11^{\prime} 2.632^{\prime \prime} \mathrm{S}, 40^{\circ} 12^{\prime} 18.218^{\prime \prime} \mathrm{W}$ & 792.4 & 05/vii/08 & $\begin{array}{l}1 \text { spm }+1 \text { stub } 1 \text { pair and } 8 \text { radular teeth }+5 \text { stubs } \\
\text { with sclerites }\end{array}$ \\
\hline ZUEC APL 292 & RJ & HAB8-A7-R1(0-2) & Habitats & $23^{\circ} 39^{\prime} 19.742^{\prime \prime} \mathrm{S}, 41^{\circ} 18^{\prime} 28.369^{\prime \prime} \mathrm{W}$ & 699 & 28/i/09 & $2 \mathrm{spms}$ \\
\hline ZUEC APL 293 & RJ & HAB8-A7-R2(2-5) & Habitats & $23^{\circ} 39^{\prime} 20.559^{\prime \prime} \mathrm{S}, 41^{\circ} 18^{\prime} 28.196^{\prime \prime} \mathrm{W}$ & 701 & 28/i/09 & $1 \mathrm{spm}+1$ slide with sclerites \\
\hline ZUEC APL 294 & RJ & HAB8-B7-R2(2-5) & Habitats & $23^{\circ} 13^{\prime} 2.799^{\prime \prime} \mathrm{S}, 40^{\circ} 57^{\prime} 37.798^{\prime \prime} \mathrm{W}$ & 741.6 & 28/i/09 & $1 \mathrm{spm}+1$ slide with sclerites \\
\hline ZUEC APL 295 & RJ & HAB8-C7-R2(0-2) & Habitats & $22^{\circ} 59^{\prime} 53.839^{\prime \prime} \mathrm{S}, 40^{\circ} 47^{\prime} 45.022^{\prime \prime} \mathrm{W}$ & 393.6 & 29/i/09 & $1 \mathrm{spm}+1$ slide with sclerites \\
\hline ZUEC APL 296 & RJ & HAB9-CANG7-R3(2-5) & Habitats & $21^{\circ} 56^{\prime} 12.105^{\prime \prime} \mathrm{S}, 39^{\circ} 57^{\prime} 45.173^{\prime \prime} \mathrm{W}$ & 720 & 07/ii/09 & $1 \mathrm{spm}+1$ slide with sclerites \\
\hline ZUEC APL 297 & RJ & HAB9-H7-R3(2-5) & Habitats & $21^{\circ} 41^{\prime} 12.521^{\prime \prime} \mathrm{S}, 40^{\circ} 1^{\prime} 56.515^{\prime \prime} \mathrm{W}$ & 702 & 06/ii/09 & $1 \mathrm{spm}$ \\
\hline ZUEC APL 298 & ES & HAB9-17-R3(0-2) & Habitats & $21^{\circ} 11^{\prime} 12.228^{\prime \prime} \mathrm{S}, 40^{\circ} 12^{\prime} 51.745^{\prime \prime} \mathrm{W}$ & 683 & 04/ii/09 & 1 stub with 1 spm \\
\hline ZUEC APL 299 & RJ & HAB13-15-R3 & Habitats & $21^{\circ} 23^{\prime} 2.093^{\prime \prime} \mathrm{S}, 40^{\circ} 15^{\prime} 9.173^{\prime \prime} \mathrm{W}$ & 145 & 06/iii/09 & 1 stub with 1 spm \\
\hline ZUEC APL 300 & RJ & HAB16-E5-R3 & Habitats & $22^{\circ} 23^{\prime} 39.088^{\prime \prime} \mathrm{S}, 40^{\circ} 20^{\prime} 41.226^{\prime \prime} \mathrm{W}$ & 150 & 04/vii/09 & $1 \mathrm{spm}+1$ slide with sclerites \\
\hline ZUEC APL 301 & RJ & HAB17-I5-R1 & Habitats & $21^{\circ} 23^{\prime} 3.544^{\prime \prime} \mathrm{S}, 40^{\circ} 15^{\prime} 9.352^{\prime \prime} \mathrm{W}$ & 140 & 21/vii/09 & 1 stub with radula \\
\hline ZUEC APL 302 & ES & AMB3-CAND4-R3(0-10) & Ambes & $19^{\circ} 31^{\prime} 51.66^{\prime \prime} \mathrm{S}, 39^{\circ} 3^{\prime} 4.04^{\prime \prime} \mathrm{W}$ & 171 & 09/xii/11 & $1 \mathrm{spm}+1$ slide with sclerites \\
\hline ZUEC APL 303 & ES & AMB5-A5-R1(2-5) & Ambes & $21^{\circ} 4^{\prime} 9.61^{\prime \prime} \mathrm{S}, 40^{\circ} 13^{\prime} 7.38^{\prime \prime} \mathrm{W}$ & 410 & $30 / x i i / 11$ & 4 spms +4 slides with sclerites \\
\hline ZUEC APL 304 & ES & AMB6-CANWN4-R3(0-10) & Ambes & $19^{\circ} 49^{\prime} 7.27^{\prime \prime} \mathrm{S}, 39^{\circ} 36^{\prime} 8.52^{\prime \prime} \mathrm{W}$ & 158 & $14 / / / 12$ & 3 spm +3 slides with sclerites \\
\hline ZUEC APL 305 & ES & AMB6-CANWN5-R3(0-10/5-10) & Ambes & $19^{\circ} 49^{\prime} 37.21^{\prime \prime} \mathrm{S}, 39^{\circ} 35^{\prime} 41.25^{\prime \prime} \mathrm{W}$ & 410 & $14 / i / 12$ & $1 \mathrm{spm}+1$ slide with sclerites \\
\hline ZUEC APL 306 & ES & AMB6-D4-R1(0-10) & Ambes & $19^{\circ} 45^{\prime} 55.39^{\prime \prime} \mathrm{S}, 39^{\circ} 30^{\prime} 25.74^{\prime \prime} \mathrm{W}$ & 149 & $15 / i / 12$ & 7 spms +7 slides with sclerites +1 stub with 1 spm \\
\hline ZUEC APL 307 & ES & AMB6-D4-R3(0-2) & Ambes & $19^{\circ} 45^{\prime} 55.39^{\prime \prime} \mathrm{S}, 39^{\circ} 30^{\prime} 25.74^{\prime \prime} \mathrm{W}$ & 149 & $15 / i / 12$ & 12 spms + 12 slides with sclerites \\
\hline ZUEC APL 308 & ES & AMB6-D4-R3(2-5) & Ambes & $19^{\circ} 45^{\prime} 55.39^{\prime \prime} \mathrm{S}, 39^{\circ} 30^{\prime} 25.74^{\prime \prime} \mathrm{W}$ & 149 & $15 / / / 12$ & 5 spms +5 slides with sclerites \\
\hline ZUEC APL 309 & ES & AMB6-E4-R3(0-2) & Ambes & $19^{\circ} 36^{\prime} 5.17^{\prime \prime} \mathrm{S}, 39^{\circ} 10^{\prime} 32.93^{\prime \prime} \mathrm{W}$ & 153 & $24 / i / 12$ & $1 \mathrm{spm}$ \\
\hline ZUEC APL 310 & ES & AMB7-B4-R2 & Ambes & $20^{\circ} 35^{\prime} 25.16^{\prime \prime} \mathrm{S}, 39^{\circ} 54^{\prime} 58.31^{\prime \prime} \mathrm{W}$ & 157 & $21 / i / 12$ & $1 \mathrm{spm}$ \\
\hline ZUEC APL 311 & ES & AMB7-D4-R2 & Ambes & $19^{\circ} 45^{\prime} 54.56^{\prime \prime} \mathrm{S}, 39^{\circ} 30^{\prime} 25.23^{\prime \prime} \mathrm{W}$ & 144 & $15 / / / 12$ & 5 spms +5 slides with sclerites \\
\hline
\end{tabular}


TABLE 1 | Continued

\begin{tabular}{|c|c|c|c|c|c|c|c|}
\hline Catalog No. & State & Station & Collector & Coordinates & Depth (m) & Date & Content \\
\hline ZUEC APL 312 & ES & AMB7-E4-R1 & Ambes & $19^{\circ} 36^{\prime} 4.32^{\prime \prime} \mathrm{S}, 39^{\circ} 10^{\prime} 34.07^{\prime \prime} \mathrm{W}$ & 147 & $15 / i / 12$ & $\begin{array}{l}1 \mathrm{spm}+2 \text { slides with with sclerites }+1 \text { stub with } 1 \\
\text { spm }\end{array}$ \\
\hline ZUEC APL 313 & ES & AMB7-E4-R2 & Ambes & $19^{\circ} 36^{\prime} 4.32^{\prime \prime} \mathrm{S}, 39^{\circ} 10^{\prime} 34.07^{\prime \prime} \mathrm{W}$ & 147 & $15 / i / 12$ & $\begin{array}{l}1 \mathrm{spm}+2 \text { slides with with sclerites }+1 \text { stub with } 1 \\
\mathrm{spm}\end{array}$ \\
\hline ZUEC APL 314 & ES & AMB7-E4-R3 & Ambes & $19^{\circ} 36^{\prime} 4.32^{\prime \prime} \mathrm{S}, 39^{\circ} 10^{\prime} 34.07^{\prime \prime} \mathrm{W}$ & 147 & $15 / / / 12$ & 1 stub with 1 spm \\
\hline ZUEC APL 315 & ES & AMB7-F2-R3 & Ambes & $18^{\circ} 52^{\prime} 32.61^{\prime \prime} \mathrm{S}, 39^{\circ} 8^{\prime} 42.82^{\prime \prime} \mathrm{W}$ & 40 & 18/i/12 & $1 \mathrm{spm}$ \\
\hline ZUEC APL 316 & ES & AMB11-A5-R1(0-2/2-5) & Ambes & $21^{\circ} 4^{\prime} 4.67^{\prime \prime} \mathrm{S}, 40^{\circ} 13^{\prime} 6.06^{\prime \prime} \mathrm{W}$ & 415 & 08/vi/13 & $3 \mathrm{spm}+3$ slides with sclerites +1 stub with $1 \mathrm{spm}$ \\
\hline ZUEC APL 317 & ES & AMB12-CAND4-R2(0-10) & Ambes & $19^{\circ} 31^{\prime} 51.68^{\prime \prime} \mathrm{S}, 39^{\circ} 3^{\prime} 4.79^{\prime \prime} \mathrm{W}$ & 171 & 29/vi/13 & 4 spms +5 slides with sclerites \\
\hline ZUEC APL 318 & ES & AMB12-CANWN4-R2(0-2) & Ambes & $19^{\circ} 49^{\prime} 6.26^{\prime \prime} \mathrm{S}, 39^{\circ} 36^{\prime} 9.34^{\prime \prime} \mathrm{W}$ & 181 & 29/vi/13 & 11 spms + 11 slides with sclerites \\
\hline ZUEC APL 319 & ES & AMB12-D4-R1(5-10) & Ambes & $19^{\circ} 45^{\prime} 53.43^{\prime \prime} \mathrm{S}, 39^{\circ} 30^{\prime} 25.97^{\prime \prime} \mathrm{W}$ & 143 & $27 / \mathrm{vi} / 13$ & $1 \mathrm{spm}+2$ slides with sclerites +1 stub with radula \\
\hline ZUEC APL 320 & ES & AMB12-D4-R3(2-5) & Ambes & $19^{\circ} 45^{\prime} 53.43^{\prime \prime} \mathrm{S}, 39^{\circ} 30^{\prime} 25.97^{\prime \prime} \mathrm{W}$ & 143 & $27 / \mathrm{vi} / 13$ & 1 spm +2 slides with sclerites \\
\hline ZUEC APL 321 & ES & AMB12-E4-R2 & Ambes & $19^{\circ} 36^{\prime} 3.57^{\prime \prime} \mathrm{S}, 39^{\circ} 10^{\prime} 33.64^{\prime \prime} \mathrm{W}$ & 143 & 29/vi/13 & 1 slide with sclerites + 1 stub with 1 spm \\
\hline ZUEC APL 322 & ES & AMB14-A4-R3 & Ambes & $21^{\circ} 4^{\prime} 4.56^{\prime \prime} \mathrm{S}, 40^{\circ} 14^{\prime} 14.08^{\prime \prime} \mathrm{W}$ & 141 & 11/vii/13 & $1 \mathrm{spm}+1$ slide with sclerites +1 slide with radula \\
\hline MZSP 38414 & $\mathrm{SP}$ & Sta. 6665 & Revizee & $25^{\circ} 26.88^{\prime} \mathrm{S}, 46^{\circ} 38.85^{\prime} \mathrm{W}$ & 80 & 16/xii/97 & $1 \mathrm{spm}+1$ slide with sclerites \\
\hline MZSP 38416 & SP & Sta. 6657 & Revizee & $25^{\circ} 17.30^{\prime} \mathrm{S}, 46^{\circ} 55.60^{\prime} \mathrm{W}$ & 60 & 09/ii/98 & $3 \mathrm{spm}$ \\
\hline MZSP 38447 & RJ & MBT 219 & MBT & $23^{\circ} 25^{\prime} 00^{\prime \prime} \mathrm{S}, 42^{\circ} 00^{\prime} 00^{\prime \prime} \mathrm{W}$ & 100 & 06/vi/71 & $2 \mathrm{spm}+1$ slide with sclerites \\
\hline MZSP 38451 & RJ & MBT 204 & MBT & $23^{\circ} 55^{\prime} 00^{\prime \prime} \mathrm{S}, 43^{\circ} 31^{\prime} 00^{\prime \prime} \mathrm{W}$ & 125 & 03/vi/71 & $4 \mathrm{spm}+1$ slide with sclerites \\
\hline MZSP 84438 & SP & Sta. 344 & Projeto Integrado & $23^{\circ} 34^{\prime} \mathrm{S}, 44^{\circ} 43^{\prime} \mathrm{W}$ & No depth & No date & $1 \mathrm{spm}+1$ slide with sclerites \\
\hline MZSP 137395 & SP & Sta. $13-\mathrm{Pl}$ & Projeto Integrado & $23^{\circ} 50^{\prime} 00^{\prime \prime} \mathrm{S}, 45^{\circ} 09^{\prime} 00^{\prime \prime} \mathrm{W}$ & 38 & $21 / i / 86$ & $1 \mathrm{spm}+1$ slide with sclerites \\
\hline MZSP 137411 & PR & Sta. 6789 & Revizee & $27^{\circ} 45^{\prime} 12.5^{\prime \prime} \mathrm{S}, 48^{\circ} 3^{\prime} 00^{\prime \prime} \mathrm{W}$ & 95 & 15/iii/98 & $1 \mathrm{spm}+1$ slide with sclerites \\
\hline MZSP 137414 & PR & Sta. 6780 & Revizee & $27^{\circ} 7^{\prime} 00^{\prime \prime} \mathrm{S}, 47^{\circ} 44^{\prime} 12.5^{\prime \prime} \mathrm{W}$ & 102 & 13/iii/98 & $1 \mathrm{spm}+1$ slide with sclerites \\
\hline MZSP 137416 & PR & Sta. 6788 & Revizee & $27^{\circ} 26^{\prime} 00^{\prime \prime} \mathrm{S}, 47^{\circ} 52^{\prime} 00^{\prime \prime} \mathrm{W}$ & 110 & 15/iii/98 & $3 \mathrm{spm}+1$ slide with sclerites \\
\hline MZSP 143012 & RS & MBT 139 & MBT & $30^{\circ} 52^{\prime} 00^{\prime \prime} \mathrm{S}, 49^{\circ} 51^{\prime} 00^{\prime \prime} \mathrm{W}$ & 126 & $27 / \mathrm{vi} / 70$ & $1 \mathrm{spm}+1$ slide with sclerites \\
\hline MZSP 154097 & RJ & HAB8-A8-R1(2-5) & Habitats & $23^{\circ} 41^{\prime} 7.814^{\prime \prime} \mathrm{S}, 41^{\circ} 16^{\prime} 4.710^{\prime \prime} \mathrm{W}$ & 1017.9 & 12/i/09 & $1 \mathrm{spm}+1$ slide with sclerites \\
\hline MZSP 154098 & ES & HAB9-17-R2(2-5) & Habitats & $21^{\circ} 11^{\prime} 12,073^{\prime \prime} \mathrm{S}, 40^{\circ} 12^{\prime} 52,126^{\prime \prime} \mathrm{W}$ & 680 & 04/ii/09 & $2 \mathrm{spm}+2$ slides with sclerites \\
\hline MZSP 154099 & ES & HAB9 I7 R3 2-5 & Habitats & $21^{\circ} 11^{\prime} 12.228^{\prime \prime} \mathrm{S}, 40^{\circ} 12^{\prime} 51.745^{\prime \prime} \mathrm{W}$ & 683 & 04/ii/09 & 4 spms +4 slides with sclerites \\
\hline MZSP 154100 & ES & AMB7-A4-R1 & Ambes & $21^{\circ} 4^{\prime} 4.76^{\prime \prime} \mathrm{S}, 40^{\circ} 14^{\prime} 14.14^{\prime \prime} \mathrm{W}$ & 153 & 23/i/12 & 7 spms +7 slides with sclerites \\
\hline MZSP 154101 & ES & AMB7-A4-R2 & Ambes & $21^{\circ} 4^{\prime} 4.76^{\prime \prime} \mathrm{S}, 40^{\circ} 14^{\prime} 14.14^{\prime \prime} \mathrm{W}$ & 153 & 23/i/12 & 8 spms +8 slides with sclerites \\
\hline MZSP 154102 & ES & AMB7-D4-R3 & Ambes & $19^{\circ} 45^{\prime} 54.56^{\prime \prime} \mathrm{S}, 39^{\circ} 30^{\prime} 25.23^{\prime \prime} \mathrm{W}$ & 144 & $15 / / / 12$ & 3 spms +3 slides with sclerites \\
\hline MZSP 154103 & ES & AMB11-B5-R1(0-10) & Ambes & $20^{\circ} 35^{\prime} 15.33^{\prime \prime} \mathrm{S}, 39^{\circ} 53^{\prime} 45.22^{\prime \prime} \mathrm{W}$ & 415 & $18 / \mathrm{vi} / 13$ & 3 spms +3 slides with sclerites \\
\hline MNRJ 23636 & RJ & HAB4-CANG7-R2(0-2) & Habitats & $21^{\circ} 56^{\prime} 10.244^{\prime \prime} \mathrm{S}, 39^{\circ} 57^{\prime} 43.438^{\prime \prime} \mathrm{W}$ & 709.7 & 28/v/08 & 2 spms +2 slides with sclerites \\
\hline MNRJ 23637 & RJ & HAB8-C6-R3(2-5) & Habitats & $22^{\circ} 59^{\prime} 0.677^{\prime \prime} \mathrm{S}, 40^{\circ} 48^{\prime} 28.837^{\prime \prime} \mathrm{W}$ & 376.6 & 31/i/09 & 2 spms +2 slides with sclerites \\
\hline MNRJ 23638 & ES & HAB9-17-R1(2-5) & Habitats & $21^{\circ} 11^{\prime} 12.170^{\prime \prime} \mathrm{S}, 40^{\circ} 12^{\prime} 51.838^{\prime \prime} \mathrm{W}$ & 682 & 04/ii/09 & 5 spms +5 slides with sclerites \\
\hline MNRJ 23639 & RJ & HAB16-H4-R1 & Habitats & $21^{\circ} 42^{\prime} 53.895^{\prime \prime} \mathrm{S}, 40^{\circ} 10^{\prime} 14.920^{\prime \prime} \mathrm{W}$ & 97 & 07/vii/09 & 3 spms +3 slides with sclerites \\
\hline MNRJ 23640 & ES & AMB7-D4-R1 & Ambes & $19^{\circ} 45^{\prime} 54.56^{\prime \prime} \mathrm{S}, 39^{\circ} 30^{\prime} 25.23^{\prime \prime} \mathrm{W}$ & 144 & $15 / / 1 / 12$ & 6 spms +6 slides with sclerites \\
\hline MNRJ 23641 & ES & AMB12-CAND6-R2(0-10) & Ambes & $19^{\circ} 37^{\prime} 45.14^{\prime \prime} \mathrm{S}, 39^{\circ} 3^{\prime} 58.75^{\prime \prime} \mathrm{W}$ & 1050 & 25/vi/13 & 4 spms +4 slides with sclerites \\
\hline CZUFS APL 11 & ES & AMB3-CAND4-R2(0-10) & Ambes & $19^{\circ} 31^{\prime} 51.66^{\prime \prime} \mathrm{S}, 39^{\circ} 3^{\prime} 4.04^{\prime \prime} \mathrm{W}$ & 171 & 09/xii/11 & 5 spms +5 slides with sclerites \\
\hline CZUFS APL 12 & ES & AMB6-E4-R3(2-5) & Ambes & $19^{\circ} 36^{\prime} 5.17^{\prime \prime} \mathrm{S}, 39^{\circ} 10^{\prime} 32.93^{\prime \prime} \mathrm{W}$ & 153 & 24/i/12 & 2 spms +2 slides with sclerites \\
\hline CZUFS APL 13 & ES & AMB12-E4-R1(2-5) & Ambes & $19^{\circ} 36^{\prime} 3.57^{\prime \prime} \mathrm{S}, 39^{\circ} 10^{\prime} 33.64^{\prime \prime} \mathrm{W}$ & 143 & 29/vi/13 & 2 spms +2 slides with sclerites \\
\hline
\end{tabular}


TABLE 2 | Percentage of contribution of environmental layers in the species distribution modeling for each species.

\begin{tabular}{lccc}
\hline Variable & S. robustus & S. ventrolineatus & $\begin{array}{c}\text { S. variabilis } \\
\text { sp. nov. }\end{array}$ \\
\hline Depth & 47.3 & 48.3 & 42.2 \\
Bottom temperature & 30.8 & 1.7 & 38.7 \\
Silicates & 11.1 & 23.9 & 8.6 \\
Slope & 4.1 & 6.4 & 6.8 \\
Primary productivity & 6.8 & 19.6 & 3.7 \\
\hline
\end{tabular}

S. robustus sounds to be unlikely for both species, as it is a region very far from European waters, where these species are recorded. Besides this, these areas of the Southern Hemisphere are still unknown regarding their diversity of caudofoveates, and future exploration may clarify if a sister species is found there.

Outside European waters, all other species of Scutopus have been reported upon by only a few studies. In the Americas, S. megaradulatus is known from the Caribbean, where it was originally described (Salvini-Plawen, 1972), and from samples from North Carolina identified by Scheltema (1981). Its occurrence from off Cape coast, South Africa (Salvini-Plawen, 1992) is presumably doubtful, and the fact that this species has an amphiatlantic distribution must be confirmed. The record of S. megaradulatus from Brazil (Rios, 1994) should definitely be discharged. In the Pacific Ocean, S. chilensis appears to be restricted to Chile (Salvini-Plawen, 1972; Osorio, 1981), and S. hamatanii and S. schanderi were only recorded from the Sea of Japan (Saito and Salvini-Plawen, 2014). Accordingly, S. variabilis sp. nov. is probably a species of restricted distribution, occurring in the shelf and the upper continental slope of the Brazilian southeastern and southern coasts; the great effort of collection was, however, restricted to this area and so its occurrence further to the north, in the northeast and north of Brazil, and in the south (Uruguay and Argentina) deserves future investigations.

The potential distribution modeling showed that the main suitable areas of $S$. variabilis sp. nov. are the Brazilian Southeastern and Southern coasts, followed by some hotspots of suitability in the Southern Caribbean Sea and Brazilian Northern coast in the Western Atlantic, mainly explained by depth and temperature. Regarding the diversity of caudofoveates, the Caribbean Sea is only known by the few and punctual records of two species (Salvini-Plawen, 1972, 1992). Although it has a tropical climate and usually very narrow continental shelves, the Caribbean Sea has hundreds of islands that create suitable areas for species with the characteristics of $S$. variabilis sp. nov. Considering that $S$, megaradulatus is already recorded from this region, the hotpots in the Caribbean Sea for S. variabilis sp. nov. are expected and should indicate that these are sister species which live in similar environmental conditions. The suitable areas found in the Brazilian Northern coast can be explained by the enlargement of the shelf close to the Amazon River mouth, creating suitable conditions for stablishing a viable population of a species of Scutopus. This area is still almost unknown regarding to its deep-sea benthic fauna. Thus, more investigations are necessary to verify if there is an isolated population of $S$. variabilis sp. nov. or a new species in the area. Outside the Western Atlantic, the suitability found in the Mediterranean sounds an unlikely occurrence area, but more investigations are required to prospect possible occurrences of $S$. variabilis sp. nov. in the islands of Angola and Cape Verde basins, where no limifossorids were described so far.

The Gulf of Mexico and the Brazilian Northeastern coast were found as unsuitable areas for $S$. variabilis sp. nov. In the Gulf of Mexico, the unsuitability reinforced our results of not finding a Scutopus species in museum collections from this area. Although the Gulf has shelf areas similar to those of the Brazilian Southeastern and Southern coasts, the existence of warmer waters in the Gulf can prevents the occurrence of suitable areas for $S$. variabilis sp. nov. Ivanov and Scheltema (2008) characterized as similar the patterns of diversity of Prochaetodermatidae from the Gulf of Mexico (7 species, 2 endemic) and the Mediterranean Sea (4 species, 1 endemic). This similarity in Prochaetodermatidae contrasts with the different pattern of Scutopus for both regions. For the Brazilian Northeastern coast, through previous analysis of material from this region any Scutopus species were found (Miranda and Passos, pers. obs.), observation that was reinforced by modeling. This non-occurrence can be explained by the tropical climate and narrow shelf characteristic of this region, which acts like a barrier that create unsuitable areas for the occurrence of S. variabilis sp. nov.

By modeling, very few and small potential overlapping areas were found, even among the European species, which in some cases were already recorded from the same geographical areas (Salvini-Plawen, 1975). In the European Atlantic, S. robustus tends to occur in the Northern areas like Iceland, Scotland and Northern Norway, whereas S. ventrolineatus mainly occurs in southern areas, between southern Norway, south of England and Bay of Biscay, with few and small overlaps in Northern Iberian Peninsula and South of Norway, as an effect of differential influences of environmental variables in both species. In relation with $S$. ventrolineatus and S. variabilis sp. nov., exceedingly small potential overlaps were found in islands of Cape Verde and Angola Basins. This suggests that competition for space and resources are reduced by occurrences of different species of Scutopus in distinct regions.

Deep-sea organisms are hard to access, as their collections are less common, the environment is less accessible, the logistics is expensive, and in many cases, species are encountered in low specimen numbers. Moreover, many cruise collections protocols still use formalin to preserve specimens, making the use of molecular techniques problematic. However, these problems have been minimized, as the number of samples of deep-sea organisms are growing in museum collections due to increasing studies required for exploitation of fisheries, oil, gas and mining, although specialists for these groups are still scarce. This is the case of Brazil, in which a great amount of useful data for taxonomy and biogeography have been available through the analysis of extensive collections, as those 
TABLE 3 | Summary data of main diagnostics characters, geographical and bathymetric distribution data of all Scutopus species described.

\begin{tabular}{|c|c|c|c|c|c|c|c|}
\hline Species & Radula Sclerotization & $\begin{array}{l}\text { Number of } \\
\text { radular } \\
\text { teeth rows }\end{array}$ & $\begin{array}{l}\text { Number of median } \\
\text { denticles of the } \\
\text { radular teeth }\end{array}$ & Suture line & $\begin{array}{l}\text { Bathymetry } \\
\quad(\mathrm{m})\end{array}$ & Distribution & References \\
\hline S. chilensis & Weakly sclerotized & $11-18$ & $18-20$ & Present & $263-642$ & $\begin{array}{l}\text { Southeastern Pacific Ocean: Chile (from } \\
\text { Valparaiso to Strait of Magellan) }\end{array}$ & $\begin{array}{l}\text { Salvini-Plawen (1972, 1992); Osoric } \\
\text { (1981); Linse (1999) }\end{array}$ \\
\hline S. hamatanii & $\begin{array}{l}\text { Sclerotized (except the } 2 \\
\text { posteriormost pairs) }\end{array}$ & 12 & $8-9$ & Present & $51-105$ & Northwestern Pacific Ocean: Sea of Japan & Saito and Salvini-Plawen (2014) \\
\hline S. megaradulatus & $\begin{array}{l}\text { Heavily Sclerotized (except } \\
\text { for the last posteriomost } \\
\text { pair) }\end{array}$ & 7 & $16-18$ & Inconspicuous & $\begin{array}{l}40-1300 \\
(1861 ?)^{\star}\end{array}$ & $\begin{array}{l}\text { Northwestern Atlantic Ocean: North } \\
\text { America, United States (North Carolina); } \\
\text { Central America, Panama, Gulf of Darien }\end{array}$ & $\begin{array}{l}\text { Salvini-Plawen (1972; 1992*); } \\
\text { Scheltema (1981); Rios }\left(1994^{\star \star} \text {, }\right. \\
\text { 2009*); Forcelli and Narosky } \\
\left(2015^{\star \star \star}\right)\end{array}$ \\
\hline S. robustus & $\begin{array}{l}\text { Heavily sclerotized (except } \\
\text { the 1-3 posteriormost pairs) }\end{array}$ & $6-10$ & $20-22$ & Absent & $\begin{array}{l}50-800 \\
(3542 ?)^{*}\end{array}$ & $\begin{array}{l}\text { Northeastern Atlantic Ocean: Norway, } \\
\text { England, Iceland, and Mediterranean }\end{array}$ & 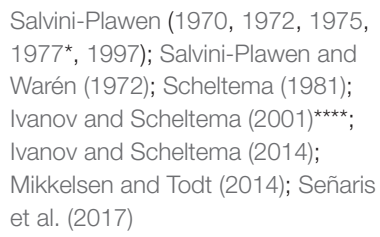 \\
\hline S. schanderi & $\begin{array}{l}\text { Heavily sclerotized (except } \\
\text { the } 2 \text { posteriormost pairs) }\end{array}$ & 8 & $16-18$ & Present & $69-102$ & Northwestern Pacific Ocean: Sea of Japan & Saito and Salvini-Plawen (2014) \\
\hline S. ventrolineatus & $\begin{array}{l}\text { Weakly sclerotized (limited } \\
\text { to the } 2-4 \text { anterior pairs) }\end{array}$ & $10-16$ & $9-11$ & Present & $40-1248$ & $\begin{array}{l}\text { Atlantic Ocean: Scandinavia (Western } \\
\text { Sweden, Norway), Western Scotland, Irish } \\
\text { Sea, Bay of Biscay and Mediterranean. } \\
\text { Southwestern Indian Ocean: off Durban, } \\
\text { South Africa, }\end{array}$ & $\begin{array}{l}\text { Salvini-Plawen (1968, 1970, 1972, } \\
\text { 1975, 1997), Osca et al. (2014) }\end{array}$ \\
\hline $\begin{array}{l}\text { Scutopus variabilis } \\
\text { sp. nov. }\end{array}$ & $\begin{array}{l}\text { Heavily sclerotized (except } \\
\text { the } 2 \text { posteriormost pairs) }\end{array}$ & 8 & $12-16$ & Present & $40-1300$ & $\begin{array}{l}\text { Southwestern Atlantic Ocean, Brazil, South } \\
\text { and Southeastern coast }\end{array}$ & This study \\
\hline
\end{tabular}

* Salvini-Plawen (1992, tab. 1) cites the occurrence of S. megaradulatus in a coordinate of western Cape of Africa at $1861 \mathrm{~m}$ depth with 2 individuals of Falcidens non-targatus, but did not illustrate the material and said that its geographical distribution is complemented in his paper. This material was not deposited in any museum, thus we did not consider this record as valid.

${ }^{* *}$ Rios $(1994,2009)$ cites the occurrence of Scutopus cf. megaradulatus and Scutopus sp. for Rios de Janeiro Coast in his Seashells catalogs, but did not furnish any bibliographical reference or material deposited in any museum, thus we did not consider this record as valid.

${ }_{* \star *}^{*}$ Forcelli and Narosky (2015) cite the occurrence of Scutopus sp. deposited in the "Museo Argentino de Ciencias Naturales "Bernardino Rivadavia" (Buenos Aires, Argentina), but this record was not confirmed in that institution (Alejandro Tablado, pers. commun.).

**** Salvini-Plawen (1977) recorded S. robustus from the Mediterranen Sea at 2415, 2917, and $3540 \mathrm{~m}$ depth, but these were considered doubtful by Ivanov and Scheltema (2001). 

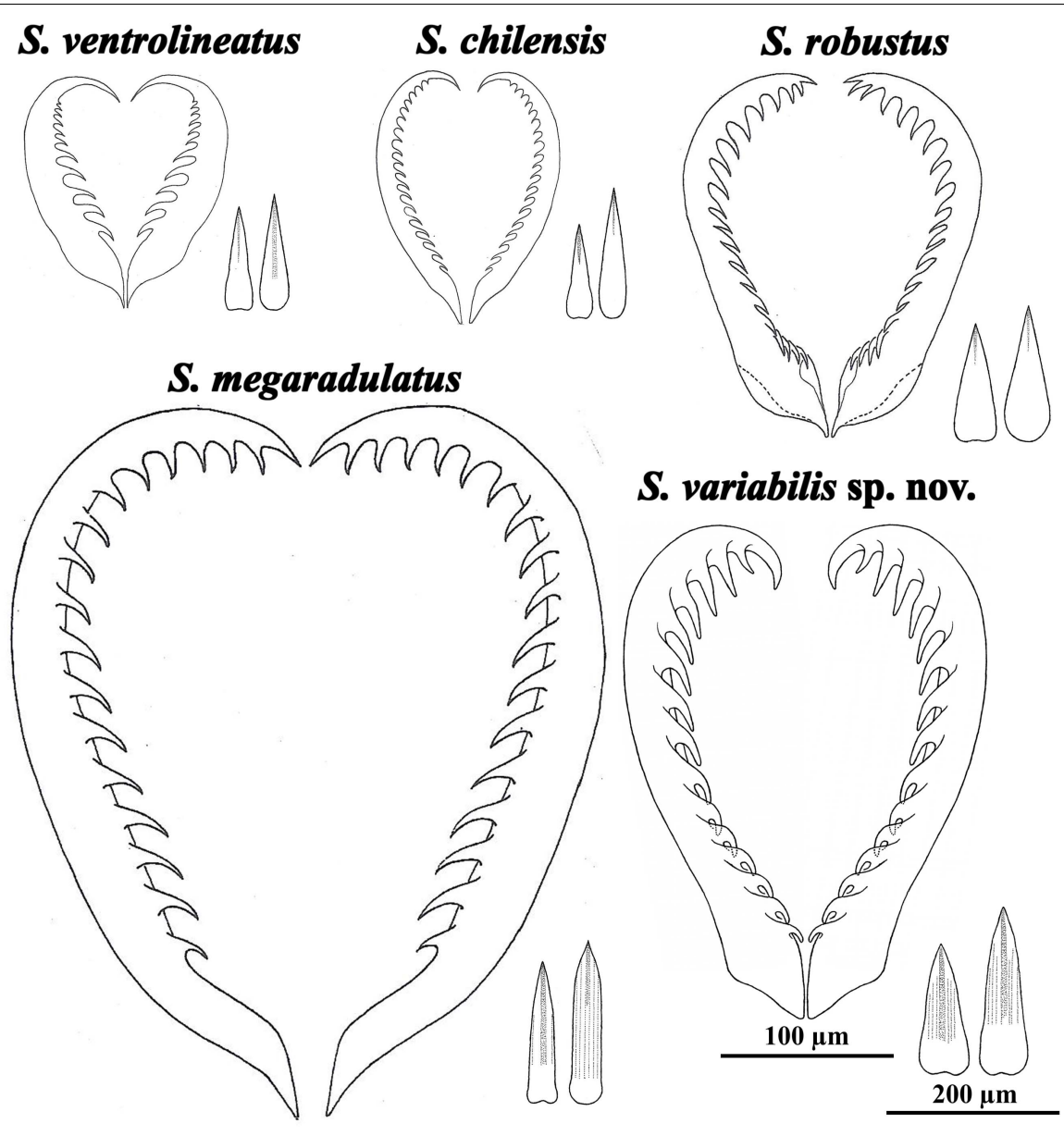

FIGURE 9 | Radula (in same scale) and trunk sclerites (idem) of Scutopus species, obtained from different sources: Salvini-Plawen (1970): figs. 1 (radula) and 3(i, I) (sclerites) of S. ventrolineatus, figs. 2 (radula) and 4(e, g) (sclerites) of S. robustus; Salvini-Plawen (1972): figs. 22 (radula) and 24(g, h) of S. megaradulatus, figs. 27 (radula) and $23(\mathrm{~m}, \mathrm{p})$ (sclerites) of $S$. chilensis. The radula of $S$. variabilis sp. nov. was drawn based on the Figure 4; its sclerites were based on the first illustrated in row $(\mathrm{E})$ and the last of row (G) of Figure 3. The radula and sclerites of the Pacific S. schanderi and S. hamatanii were illustrated by Saito and Salvini-Plawen (2014).

made by the "Habitats" and "Ambes" projects. With these and in association with examination of other museums samples, a species distribution modeling was performed, this being a quantitative technique that started to be used only recently for deep-sea organisms (e.g., Basher and Costello, 2016; Schnurr et al., 2018; Bowden et al., 2021); it is used here for the first time for aplacophoran molluscs.

As it occurs with other deep-water animals, Aplacophora is a clear example of lesser-known group. However, especially in the last decade, this scenario is rapidly changing (Todt, 2013; Passos et al., 2019). Some techniques, like SEM and birefringence microscopy, particularly important for the study of these animals, are becoming more accessible (e.g., Corrêa et al., 2014, 2018; Mikkelsen and Todt, 2014; Passos et al., 2018; Saito, 2020), making the descriptions more detailed; moreover, previous molecular obstacles have been surpassed (e.g., Kocot et al., 2011; Mikkelsen et al., 2018, 2019; Bergmeier et al., 2021). Museum collections are increasingly with materials coming from new unexplored areas like the South Atlantic, allowing studies by recent biogeographical and ecological techniques, like species distribution modeling. In the specific literature on aplacophorans, there are some citations of undescribed species of Scutopus, for example, from off California and Oregon, United States (Barwick and Cadien, 2005; Mikkelsen et al., 2019), and Chile (Linse, 1999), and in fact there are large areas of the Pacific and Indian Oceans which are still very poorly sampled. As a part of a larger project that has been performed on the molluscan diversity of the Brazilian coast, in comparison with other Atlantic species (Corrêa et al., 2014, 2018; Passos et al., 2018, 2019; Miranda et al., 2020), this study gives a little step toward a better knowledge of these animals from the deep-sea of the Southern Hemisphere.

\section{DATA AVAILABILITY STATEMENT}

The original contributions presented in the study are included in the article/Supplementary Material, further inquiries can be directed to the corresponding author. 


\section{AUTHOR CONTRIBUTIONS}

FP designed the study and prepared the text. PC conducted the morphological analysis, species distribution modeling, and made a critical review of the final version of the manuscript. MM designed the study, conducted the morphological analysis, species distribution modeling, and prepared the text. All authors contributed to the article and approved the submitted version.

\section{FUNDING}

This work was supported by the Centro de Pesquisas Leopoldo Américo Miguez de Mello (CENPES/Petrobras), Fundação de Amparo à Pesquisa do Estado de São Paulo (FAPESP) (grants numbers 2011/502917-4, 2018/06347-6, and 2018/10313-0), and Fundo de Apoio ao Ensino, à Pesquisa e à Extensão (FAEPEX) (grant number 362/2012) for FP. Scholarships were furnished for MM and PC by Capes and FAPESP (grants number 2017/01081-5 and 2018/17718-5).

\section{REFERENCES}

Barwick, K., and Cadien, D. (2005). Aplacophore Mollusks of the 2003 Regional Monitoring Survey of the Southern California Bight. SCAMIT Suppl. 23:66.

Basher, Z., Bowden, D. A., and Costello, M. J. (2018). Global Marine Environment Datasets (GMED). World Wide Web electronic publication. Version 2.0 (Rev.02.2018). Available online at: http://gmed.auckland.ac.nz on (Accessed June 23, 2021)

Basher, Z., and Costello, M. J. (2016). The past, present and future distribution of a deep-sea shrimp in the Southern Ocean. PeerJ. 4:e1713. doi: 10.7717/peerj. 1713

Bergmeier, F. S., Brandt, A., Schwabe, E., and Jörger, K. M. (2017). Abyssal Solenogastres (Mollusca, Aplacophora) from the Northwest Pacific: scratching the Surface of Deep-Sea Diversity Using Integrative Taxonomy. Front. Mar. Sci. 4:410. doi: 10.3389/fmars.2017.00410

Bergmeier, F. S., Haszprunar, G., Brandt, A., Saito, H., Kano, Y., and Jörger, K. M. (2019). Of basins, plains and trenches: systematics and distribution of Solenogastres (Mollusca, Aplacophora) in the Northwest Pacific. Prog. Oceanogr. 178:102187. doi: 10.1016/j.pocean.2019.102187

Bergmeier, F. S., Ostemair, L., and Jörger, K. M. (2021). Specialized predation by deepsea Solenogastres revealed by sequencing of gut contents. Curr. Biol. 31, R836-R837. doi: 10.1016/j.cub.2021.05.031

Bowden, D. A., Anderson, O. F., Rowden, A. A., Stephenson, F., and Cark, M. R. (2021). Assessing Habitat Suitability Models for the Deep Sea: is Our Ability to Predict the Distributions of Seafloor Fauna Improving? Front. Mar. Sci. 8:632389. doi: $10.3389 /$ fmars.2021.632389

Boyko, C. B., and Sage, W. E. III (1996). Catalog of recent type specimens in the Department of Invertebrates, American Museum of Natural History. II. Mollusca Part 1 (Classes Aplacophora, Polyplacophora, Gastropoda [Subclass Opisthobranchia], Bivalvia, and Scaphopoda). Am. Mus. Novit. 3170, 1-50. doi: 10.1206/0003-0090(2001)262<0001:cortsi>2.0.co;2

Cobo, M. C., and Kocot, K. M. (2020). Micromenia amphiatlantica sp. nov.: first solenogaster (Mollusca, Aplacophora) with an amphi-Atlantic distribution and insight into abyssal solenogaster diversity. Deep Sea Res. 1 Oceanogr. Res. Pap. 157:103189. doi: 10.1016/j.dsr.2019.103189

Corrêa, P. V. F., Fassina, P. V., and Passos, F. D. (2014). Falcidens targatus and F. acutargatus: two species of Caudofoveata (Mollusca, Aplacophora) new for Brazil. J. Nat. Hist. 48, 2947-2963. doi: 10.1080/00222933.2014.959575

Corrêa, P. V. F., Miranda, M. S., and Passos, F. D. (2018). South America-Africa missing links revealed by the taxonomy of deep-sea molluscs: examples from prochaetodermatid aplacophorans. Deep Sea Res. 1 Oceanogr. Res. Pap. 132, 16-28. doi: 10.1016/j.dsr.2017.12.008

\section{ACKNOWLEDGMENTS}

Thanks are due to AP Falcão, who invited FP to participate as a taxonomist of the "Habitats" and "Ambes" Project; ACS Sprogis and SMF Ferraz (Laboratório de Microscocopia Eletrônica IB/UNICAMP), who helped in the techniques of microscopy; and LRL Simone, EE Strong, and AJ Baldinger for their kind reception of MM in the MZSP, USNM, and MCZ, respectively; NC Barrera (Texas A\&M University) is also acknowledged for kindly commenting on the aplacophorans from the Gulf of Mexico. We also thank the editors Stephanie Kaiser and Kevin Kocot, and four reviewers for their useful comments that improved the final version of this manuscript.

\section{SUPPLEMENTARY MATERIAL}

The Supplementary Material for this article can be found online at: https://www.frontiersin.org/articles/10.3389/fmars. 2021.669478/full\#supplementary-material

Forcelli, D. O., and Narosky, T. (2015). Uruguayan Seashells - Moluscos Marinos Argentina, Uruguay and Brazil. Buenos Aires: Marquez Martini.

Ivanov, D. L. (1981). Caudofoveatus tetradens gen. et sp. n. and diagnosis of taxa in the subclass Caudofoveata (Mollusca, Aplacophora). Zool. Zh. 60, 18-28.

Ivanov, D. L., Mikkelsen, N. T., and Schander, C. (2009). Falcidens sagittiferus Salvini-Plawen, 1968: additional data on morphology and distribution (Mollusca. Aplacophora, Caudofoveata). Fauna Norv. 29, 3-9. doi: 10.5324/ fn.v29i0.610

Ivanov, D. L., and Scheltema, A. H. (2001). Distribution of known caudofovetate species (Mollusca. Aplacophora) around Iceland. Ruthenica. 11, 1-6. doi: 10. 1080/00364827.1989.10413419

Ivanov, D. L., and Scheltema, A. H. (2008). Western Atlantic Prochaetodermatidae from $35^{\circ} \mathrm{N}$ to the Argentine Basin including the Gulf of Mexico. Zootaxa 1885, 1-60. doi: 10.11646/zootaxa.1885.1.1

Ivanov, D. L., and Scheltema, A. H. (2014). Deep-sea fauna of European seas: an annotated species check-list of benthic invertebrates living deeper than $2000 \mathrm{~m}$ in the seas bordering Europe. Aplacophora. Invert. Zool. 11, 8-12.

Kocot, K. M., Cannon, J. T., Todt, C., Citarella, M. R., Koln, A. B., Meyer, A., et al. (2011). Phylogenomics reveals deep molluscan relationships. Nature 477, 452-456. doi: 10.1038/nature10382

Linse, K. (1999). Mollusca of the Magellan region. A checklist of the species and their distribution. Sci. Mar. 63, 399-407. doi: 10.3989/scimar.1999.63s1399

Machado, F. M., and Passos, F. D. (2016). Spheniopsidae Gardner, 1928 (Bivalvia): conchological characters of two new species from off Brazil, southwestern Atlantic. Am. Malac. Bull. 33, 212-220. doi: 10.4003/006.033.0207

Mikkelsen, N. T., Kocot, K. M., and Halanych, K. M. (2018). Mitogenomics reveals phylogenetic relationships of caudofoveate aplacophoran molluscs. Mol. Phylogenet. Evol. 127, 429-436. doi: 10.1016/j.ympev.2018.04.031

Mikkelsen, N. T., and Todt, C. (2014). Diversity of Caudofoveata (Mollusca) around Iceland and description of Psilodens balduri sp. n. Pol. Polar Res. 35, 279-290. doi: 10.2478/popore-2014-0014

Mikkelsen, N. T., Todt, C., Kocot, K. M., Halanych, K. M., and Willasen, E. (2019). Molecular phylogeny of Caudofoveata (Mollusca) challenges traditional views. Mol. Phylogenet. Evol. 132, 138-150. doi: 10.1016/j.ympev.2018.10.037

Miranda, M. S., Strong, E. E., and Passos, F. D. (2020). Type specimens of Caudofoveata (Mollusca, Aplacophora) in the molluscan collections of the National Museum of Natural History, Smithsonian Institution, and of the Museum of Comparative Zoology, Harvard University. Zootaxa 4895, 581-593. doi: 10.11646/zootaxa.4895.4.8

Morueta-Holme, N., Fløjgaard, C., and Svenning, J. C. (2010). Climate change risks and conservation implications for a threatened small-range mammal species. PLoS One 5:e10360. doi: 10.1371/journal.pone.0010360 
Osca, D., Irisarri, I., Todt, C., Grande, C., and Zardoya, R. (2014). The complete mitochondrial genome of Scutopus ventrolineatus (Mollusca: Chaetodermomorpha) supports the Aculifera hypothesis. BMC Evol. Biol. 14:197. doi: 10.1186/s12862-014-0197-9

Osorio, C. (1981). Caudofoveata y Solenogastra de Chile. Bol. Soc. Biol. Concepc. $52,115-128$.

Passos, F. D., Corrêa, P. V. F., and Todt, C. (2018). A new species of Falcidens (Mollusca, Aplacophora, Caudofoveata) from the southeastern Brazilian coast: external anatomy, distribution, and comparison with Falcidens caudatus (Heath, 1918) from the USA. Mar. Biodivers. 48, 1135-1146. doi: 10.1007/ s12526-016-0559-1

Passos, F. D., and Machado, F. M. (2014). A New Species of Cyamiocardium Soot-Ryen, 1951 from Shallow Waters off Brazil, with a Discussion on the Anatomical Characters of the Cyamiidae (Bivalvia: Cyamioidea). Am. Malac. Bull. 32, 122-131. doi: 10.4003/006.032.0110

Passos, F. D., Miranda, M. S., and Corrêa, P. V. F. (2019). Synopsis of the knowledge on the Brazilian aplacophorans (Mollusca: Caudofoveata and Solenogastres). Biota Neotrop. 19:e20180545. doi: 10.1590/1676-0611-BN-2018-0545

Phillips, S. J., Anderson, R. P., and Schapire, R. E. (2006). Maximum entropy modeling of species geographic distributions. Ecol. Model. 190, 231-259. doi: 10.1016/j.ecolmodel.2005.03.026

Pires-Vanin, A. M. S., and Matsuura, Y. (1993). Estrutura e função do ecossistema de plataforma continental da região de Ubatuba, Estado de São Paulo: uma introdução. Publ. Esp. Inst. Oceanogr. 10, 217-231.

Rios, E. C. (1994). Seashells of Brazil 4th ed. Rio Grande: Universidade do Rio Grande.

Rios, E. C. (2009). Compendium of Brazilian Seashells. Rio Grande: Evengraf.

Saito, H. (2020). A new species of Falcidens (Mollusca: Caudofoveata: Chaetodermatidae) from the Pacific Coast of Japan. Bull. Natl. Mus. Nat. Sci. $46,79-87$.

Saito, H., and Salvini-Plawen, L. V. (2014). Four new species of the aplacophoran class Caudofoveata (Mollusca) from the southern Sea of Japan. J. Nat. Hist. 48, 2965-2983. doi: 10.1080/00222933.2014.959577

Salvini-Plawen, L. V. (1968). Über Lebendbeobachtungen an Caudofoveata (Mollusca, Aculifera), nebst Bemerkungen zum System der Klasse. Sarsia 31, 105-126. doi: 10.1080/00364827.1968.10411115

Salvini-Plawen, L. V. (1969). Solenogastres und Caudofoveata (Mollusca, Aculifera): organisation und phylogenetische bedeutung. Malacologia 9, 191216.

Salvini-Plawen, L. V. (1970). Die norwegischen Caudofoveata. Sarsia 45, 1-15. doi: 10.1080/00364827.1970.10411180

Salvini-Plawen, L. V. (1972). "Die Caudofoveata des Mittelmeeres und das Genus Scutopus (Mollusca, Aculifera)," in Fifth European Marine Biology Symposium; 1970 ed, ed. B. Battaglía (Padova: Piccin Editore), 27-51.

Salvini-Plawen, L. V. (1975). Mollusca: Caudofoveata. Marine invertebrates of Scandinavia (4). Oslo: Scandinavian University Books.

Salvini-Plawen, L. V. (1977). Caudofoveata (Mollusca) des Forschungsprojektes Polymède. Bull. Mus. Natl. Hist. Nat. 3, 413-421.

Salvini-Plawen, L. V. (1990). Origin, phylogeny and classification of the phylum Mollusca. Iberus 9, 1-33.

Salvini-Plawen, L. V. (1992). "On certain Caudofoveata from the VEMAExpedition," in Proceedings of the 9th International Malacological Congress (Edinburgh 1986), eds E. Gittenberger and J. Gould (Leiden: Unitas Malacologica), 317-333.

Salvini-Plawen, L. V. (1997). Fragmented knowledge on West-European and Iberian Caudofoveata and Solenogastres. Iberus 15, 35-50.

Salvini-Plawen, L. V. (2003). On the phylogenetic significance of the aplacophoran Mollusca. Iberus 21, 67-97.

Salvini-Plawen, L. V., and Warén, A. (1972). Skandinasvische Caudofoveata (Mollusca): nachtrag. Sarsia 51, 3-6. doi: 10.1080/00364827.1972.10411220

Schander, C., Scheltema, A. H., and Ivanov, D. L. (2006). Falcidens halanychi, a new species of Chaetodermomorpha (=Caudofoveata) (Mollusca) from the northwest Atlantic Ocean. Mar. Biol. Res. 2, 303-315. doi: 10.1080/ 17451000600798795
Scheltema, A. H. (1981). Comparative morphology of the radula and alimentary tracts in the Aplacophora. Malacologia 20, 361-383.

Scheltema, A. H. (1985). The aplacophoran family Prochaetodermatidae in the North American Basin, including Chevroderma n.g. and Spathoderma n.g. (Mollusca; Chaetodermomorpha). Biol. Bull. 169, 484-529. doi: 10.2307/ 1541497

Scheltema, A. H. (1987). Reproduction and rapid growth in a deep-sea aplacophoran mollusc, Prochaetoderma yongei. Mar. Ecol. Prog. Ser. 37, 171180. doi: $10.3354 /$ meps037171

Scheltema, A. H. (1997). Aplacophoran molluscs: deep-sea analogs to polychaetes. Bull. Mar. Sci. 60, 575-583.

Scheltema, A. H., and Ivanov, D. L. (2000). Prochaetodermatidae of the Eastern Atlantic Ocean and Mediterranean Sea (Mollusca: Aplacophora). J. Molluscan Stud. 66, 313-362. doi: 10.1093/mollus/66.3.313

Scheltema, A. H., and Ivanov, D. L. (2009). A natural history of the deepsea aplacophoran Prochaetoderma yongei and its relationship to confamilials (Mollusca, Prochaetodermatidae). Deep Sea Res. II Top. Stud. Oceanogr. 56, 1856-1864. doi: 10.1016/j.dsr2.2009.05.026

Scheltema, A. H., Tscherkassky, M., and Kuzirian, A. M. (1994). “Aplacophora, in Microscopic Anatomy of Invertebrates. Volume 5: The Mollusca, eds F. W. Harrison and A. J. Kohn (New York: Wiley - Liss, Inc), 13-54.

Schnurr, S., Osborn, K. J., Malyutina, M., Jennings, R., Brix, S., Driskell, A., et al. (2018). Hidden diversity in two species complexes of munnopsid isopods (Crustacea) at the transition between the northernmost North Atlantic and the Nordic Seas. Mar. Biodivers. 48, 813-843. doi: 10.1007/s12526-0180877-6

Señaris, M. P., García-Álvarez, O., and Urgorri, V. (2017). The habitus of Scutopus robustus Salvini-Plawen, 1970 (Caudofoveata, Limifossoridae), a rare mollusc from the NW Iberian Peninsula. Mar. Biodivers. 47, 377-378. doi: 10.1007/ s12526-016-0488-z

Smith, S. A., Wilson, N. G., Goetz, F. E., Feehery, C., Andrade, S. C. S., Rouse, G. W., et al. (2011). Resolving the evolutionary relationships of molluscs with phylogenomic tools. Nature 480, 364-367. doi: 10.1038/nature10526

Todt, C. (2013). Aplacophoran Mollusks-Still Obscure and Difficult?. Am. Malacol. Bull. 31, 181-187. doi: 10.4003/006.031.0110

Treece, G. D. (1979). Four new records of aplacophorous mollusks from the Gulf of Mexico. Bull. Mar. Sci. 29, 344-364.

Vinther, J., Parry, L., Briggs, D. E. G., and Roy, P. (2017). Ancestral morphology of crowngroup molluscs revealed by a new Ordovician stem aculiferan. Nature 542, 471-474. doi: 10.1038/nature21055

Vinther, J., Sperling, E. A., Briggs, D. E. G., and Peterson, K. J. (2012). A molecular palaeobiological hypothesis for the origin of aplacophoran molluscs and their derivation from chiton-like ancestors. Proc. R. Soc. B. 279, 1259-1268. doi: 10.1098/rspb.2011.1773

Warren, D. L., Glor, R. E., and Turelli, M. (2010). ENMTools: a toolbox for comparative studies of environmental niche models. Ecography 33, 607-611. doi: $10.1111 / \mathrm{j} .1600-0587.2009 .06142 . \mathrm{x}$

Conflict of Interest: The authors declare that the research was conducted in the absence of any commercial or financial relationships that could be construed as a potential conflict of interest.

Publisher's Note: All claims expressed in this article are solely those of the authors and do not necessarily represent those of their affiliated organizations, or those of the publisher, the editors and the reviewers. Any product that may be evaluated in this article, or claim that may be made by its manufacturer, is not guaranteed or endorsed by the publisher.

Copyright (c) 2021 Passos, Corrêa and Miranda. This is an open-access article distributed under the terms of the Creative Commons Attribution License (CC BY). The use, distribution or reproduction in other forums is permitted, provided the original author(s) and the copyright owner(s) are credited and that the original publication in this journal is cited, in accordance with accepted academic practice. No use, distribution or reproduction is permitted which does not comply with these terms. 